\title{
Banks and Innovation: Microeconometric Evidence on Italian Firms*
}

\author{
Luigi Benfratello (Università di Torino) \\ Fabio Schiantarelli (Boston College and IZA) \\ Alessandro Sembenelli (Università di Torino and Collegio Carlo Alberto)
}

June 8, 2007

\begin{abstract}
In this paper we investigate the effect of local banking development on firms' innovative activities, using a rich data set on innovation for a large number of Italian firms over the 1990's. There is evidence that banking development affects the probability of process innovation, particularly for firms in high-tech sectors, in sectors more dependent upon external finance, and for firms that are small. The evidence for product innovation is much weaker and not robust. There is also some evidence that banking development reduces the cash flow sensitivity of fixed investment spending, particularly for small firms, and that it increases the probability they will engage in R\&D.
\end{abstract}

JEL Classification: D24, G21, G38, O31, O33

Keywords: Banks, Financial Development, Innovation, R\&D, Investment

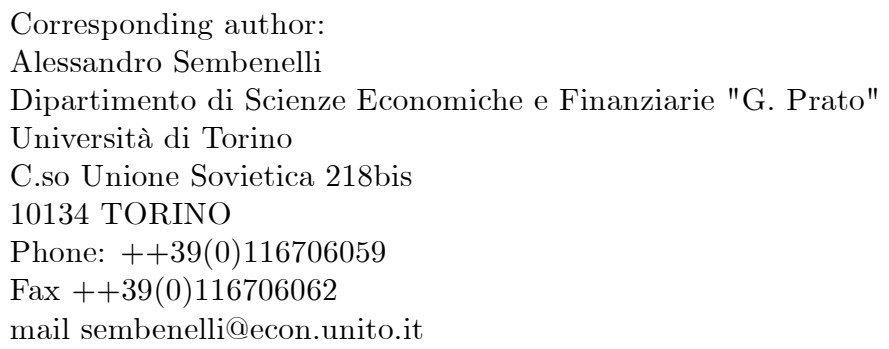

${ }^{*}$ We thank P. Angelini, O. Bover, R. Carrasco, M. Das, S. Greenstein, L. Guiso, A. Lewbel, F. Lotti, R. Minetti, P. Mistrulli, J. Wooldridge, L. Zingales and seminar participants at Banca d'Italia, Banco de España, European University Institute, NBER Summer Institute, IIOC 2006 Conference as well as at Brescia, Salerno and Pescara Universities for useful comments, suggestions, and conversations. We also thank Giorgio Gobbi, Luigi Guiso, and Sergio Lugaresi for providing us with some of the data used in this study. 


\title{
Banks and Innovation: Microeconometric Evidence
}

\author{
on Italian Firms
}

June 8, 2007

\begin{abstract}
In this paper we investigate the effect of local banking development on firms' innovative activities, using a rich data set on innovation for a large number of Italian firms over the 1990's. There is evidence that banking development affects the probability of process innovation, particularly for firms in high-tech sectors, in sectors more dependent upon external finance, and for firms that are small. The evidence for product innovation is much weaker and not robust. There is also some evidence that banking development reduces the cash flow sensitivity of fixed investment spending, particularly for small firms, and that it increases the probability they will engage in R\&D.
\end{abstract}

JEL Classification: D24, G21, G38, O31, O33

Keywords: Banks, Financial Development, Innovation, R\&D, Investment 


\section{Introduction}

Does banking development stimulate the introduction of innovations? The answer to this question is crucial in understanding how financial development and its nature affect a country's growth prospects. The effect of financial development on real development has been investigated in many recent papers and the empirical evidence suggests a positive effect of financial development on GDP and TFP growth, while its impact on the quantity of aggregate investment is instead debatable. ${ }^{1}$ This suggests that the effect of financial development on the efficiency with which resources are allocated may be what matters most. The ability of the financial system to allocate funds to the highest return projects has characterized the theoretical literature, but there is little direct evidence on this issue. ${ }^{2}$ More specifically, we do not know much about the effect of banking development on the pace of technological progress, although the role of financial intermediaries in selecting more capable innovators may be the key mechanism through which GDP growth is affected, as emphasized by King and Levine (1993a, 1993b) in the context of an endogenous growth model.

A direct empirical investigation of the effect of banking development on firm's innovative activities is exactly what we carry out in this paper. We use a rich data set on innovation at the firm level collected by Capitalia's Observatory of SME's for a large number of Italian firms over the 90's that contains detailed categorical information on the introduction of process and product innovation. Moreover, the data set contains quantitative information on inputs of the innovation process at the firm level, such as $R \& D$ spending and fixed investment, and on the way they are financed, in addition to standard

\footnotetext{
${ }^{1}$ Many studies are based on cross sectional growth regressions (see, for instance, King and Levine (1993a, 1993b), Levine (1997), Levine and Zervos (1998)), others on pooled time series-cross sectional country level data (see Beck et al. (2000) and Levine et al. (2000)). For a different approach see Rajan and Zingales (1998) who rely on industry level data to show that industries with the greater need of external finance, grow faster in more financially developed countries. Guiso, Jappelli, Padula, and Pagano (2004) confirm this result for a larger set of countries. They use also firm level data to show that small firms benefit more than large ones from financial development. Demirguc-Kunt and Maksimovic (1998) show that firms grow at a faster rate, relative to a benchmark growth rate that would hold in the absence of external finance, in countries with a more developed financial system. Finally, see Bekaert et al. (2005) and Henry (2000) for evidence on the effect of stock market liberalization on growth and investment respectively.

${ }^{2}$ See, for instance, the theoretical contributions of Greenwood and Jovanovic (1990), Bencivenga and Smith (1991), Saint Paul (1992). Empirical evidence on this issue is limited. Beck et al. (2000) find that measures of financial development have a positive effect on aggregate TFP growth. Wurgler (2000) and Galindo et al. (2007) present evidence on the beneficial effect of financial development or reform on the allocation of investment funds, using, respectively, industry or firm level data.
} 
firm balance sheet variables. The availability of direct input and output measures of the innovation process allows us to address the issue of the effect of banks on innovation head on, instead of having to make inferences about it from the observed effect of banking development on TFP and GDP growth.

Focusing on Italy is very informative because it allows us to isolate the role of banks in fostering innovation. The financial system in Italy can definitely be characterized as bank-based, and the stock market plays a very limited role in providing external finance to firms at any stage of their life cycle. Banking development is likely to be particularly important for firms in sectors with greater need for external finance. Moreover, there is considerable spatial diversity in the degree of banking development, and it is reasonable to assume that "distance" matters in banking relationships, particularly for certain types of firms that may experience more difficulties in accessing security markets. Finally, the process of regulatory reform in the late 80 's and 90 's has led to important changes both in the size and structure of the banking sector. A large fraction of the spatial diversity observed has been generated by the nature of banking regulation in effect from 1936 to the end of the 80's. As suggested by Guiso et al. (2004a, 2004b), the partly exogenous geographical variation in banking development may help in identifying its effect on real outcomes (innovation in our case). In addition, we can rely on a sizeable geographical diversity in the pace of evolution of the banking sector over time in order to assess its impact on innovation.

Certainly we are not the first ones to investigate the real consequences of changes in the financial system at the local level. Several recent contributions have greatly enhanced our understanding in this area. ${ }^{3}$ However, this is the first paper that investigates the complex link between development of the banking sector and innovation at the firm level, either within countries or across countries. Evidence on this issue is potentially very important in understanding one of the main channels through which

\footnotetext{
${ }^{3}$ Petersen and Rajan (1995) look at the effect of concentration in US local markets on lending relationships. Jayaratne and Strahan (1996) analyze the effect of banking deregulation in the US on growth, while Black and Strahan (2002) focus on its effect on entrepreneurship and credit availability, and Cetorelli and Strahan (2006) on the relationship between bank competition and industry structure. There are several contributions for Italy. Angelini and Cetorelli (2003) study the effect of regulatory reform on banks' markups. Bonaccorsi di Patti and Gobbi (2001) investigate the effect of competition on the availability of credit. Bonaccorsi di Patti and Dell'Ariccia (2004) focus on firms' creation. Guiso et al. (2004a) present evidence of the effect of local financial development on a wide set of outcomes, such as business formation and firm entry and growth. Guiso et al. (2004b) study the effect of banking regulation on the cost and access to credit.
} 
financial development affects growth. The focus of our paper is the impact of banking development on innovation along the extensive margin, captured by the evolution in bank branch density. In this sense it differs from Herrera and Minetti (2007) who study the effect on Italian firms' innovations of the depth of banking relationship at a point in time. It also differs from Atanassov et al. (2005) who focus on the advantage of arm's length borrowing, relative to relationship borrowing, in developing breakthrough innovations for US companies.

The structure of the paper is as follows. In Section 2 we will discuss the potential channels through which banking development may affect the introduction of innovations. In Section 3 we will describe the data sets we will use and provide descriptive evidence on the evolution of the banking sector in Italy in the 90's and on the innovative activities of Italian firms. In Section 4 and 5 we present the econometrics results. Section 6 concludes.

\section{The Link between Innovation and Banking Development}

A useful way to organize our analysis of the link between banking development and innovation is to think of the inputs in the process generating an innovation. ${ }^{4}$ In this context, the probability of introducing an innovation depends upon inputs internal to the firm (such as R\&D and fixed investment) and external to the firm. The degree of development of the banking sector is one of the external inputs that can affect the innovation output, for a given quantity of internal inputs. This is because banking development may affect the nature of the selected project, the quality of internal inputs and their effectiveness in generating innovations. Moreover, it has a direct effect on the quantity of R\&D and investment spending. Finally, a more developed and advanced banking sector may be particularly beneficial in relaxing financial constraints for informationally opaque firms that are more dependent upon local financial intermediaries, and for activities that require greater access to external finance.

The idea that the development of financial intermediaries reduces the cost of acquiring information and allows a better assessment, selection, and monitoring of investment projects is central in explaining

\footnotetext{
${ }^{4}$ See for instance the seminal contribution by Griliches (1979).
} 
the role of banks in the growth process. The ability of financial intermediaries to improve information collection, with the resulting increase in the efficiency of resource allocation and hence growth, lies at the center of the theoretical contribution of Greenwood and Jovanovic (1990). More importantly for our purpose, King and Levine (1993a) emphasize the role of intermediaries in reducing the resource cost of identifying those entrepreneurs who are more capable of generating an innovation. The fostering of innovations is therefore the key channel through which financial development affects growth.

We have argued (and we will document in details in the next section) that there are substantial variations in Italy both in the level and the pace of banking development at the provincial level. In the aftermath of banking deregulation, one can think of several channels through which local banking development may affect firms' innovative activities. To start with, it is likely that banking development generates an outward shift in the supply of credit and a decrease in the mark-up in the banking sector, leading to a more ample supply of funds and lower rates for all investment projects, including those involving product or process innovations. The evidence contained in Angelini and Cetorelli (2003) suggests indeed that banking deregulation in Italy has led to a decrease in the mark-up applied by banks over the cost of funds.

In our empirical work, we will use the number of bank branches in a province divided by population as our main indicator of banking development. This branch density measure is also an inverse measure of distance between borrower and lenders. Geographical closeness may allow banks to be more effective in collecting soft information on borrowers and to reduce screening and monitoring costs, particularly for small firms. A decrease in such costs has beneficial effects on the cost of and access to finance in a variety models with asymmetric information. ${ }^{5}$

It has been argued that with the greater use of computers and communication equipment the importance of distance for small firms may be decreasing in countries such as the US (see Petersen and Rajan (1995)). However, there is ample evidence for Italy that distance between borrowers and bank branches still matters. Bonaccorsi di Patti and Gobbi (2001) find that branch density exerts a

\footnotetext{
${ }^{5}$ Within a costly state verification framework, for instance, it reduces the likelihood of rationing equilibria and increases the equilibrium level of investment when they occur (see Williamson (1986), (1987))
} 
positive effect on credit flows, particularly to small firms, and it reduces the percentage of bad loans. Alessandrini et al. (2006) present evidence that higher branch density reduces the probability of being financially constrained ${ }^{6}$

Another channel through which the growth in branches can affect innovation is through its impact on competition. In the context of a monopolistically competitive banking system, Harrison et al (2004) show that the effect of entry is ambiguous. On the one hand, the average distance between the bank and the borrowing firm falls and this in turn decreases transportation and monitoring costs. On the other hand, since monitoring is intensive in labor input, wages and consequently the cost of intermediation, will also increase. In addition, increasing phisical proximity between the borrower and the lender may generate greater market power for the lender, resulting in higher interest rates. However, also the distance between the borrower and the closest competing bank decreases, as well as the distance between the lender and its competitors. This may reduce the cost of loans. Moreover, greater competition may induce an increase in relationship lending, to the benefit of more informationally opaque borrowers, because relationship lending insulates banks from pure price competition (Boot and Thakor $(2000))^{7}$

Finally, it has been argued that the turmoil and changes brought about by the entry of new banks in the local markets may hurt small firms. Petersen and Rajan (1995), for instance, suggest that more competitive and less concentrated credit markets may make it more difficult for borrowers and lenders to intertemporally share surplus and present evidence for small US firms that the cost of credit indeed decreases with concentration, while its availability increases.

Summarizing, there are strong reasons to believe that banking development, as captured by an increase in branch density, can have beneficial effects on the financing of innovation, because of the decrease in screening and monitoring costs, outward shift in the supply of credit, and increase in

\footnotetext{
${ }^{6}$ In Alessandrini et al. (2006) branch density captures what they define "operational" distance. They also calculate "functional" distance between banks and local communities, where the number of branches is weighted by the distance between branch and headquarter. Functional distance is found to increase financing constraints.

${ }^{7}$ The empirical contributions by Berger and Udell (2002) and Carpenter and Petersen (2002) highlight the importance of relationship lending, in which banks acquire information through repeated contacts with the firm, its owner and its local communitiy and use this soft information in their decision on the availability and cost of credit for a firm.
} 
competition. However, the increase in competition may also disrupt the financing of more opaque borrowers such as small firms, so that the sign and magnitude of the effect of an increase in bank density is ultimately an empirical issue.

The overall empirical evidence on the effect of bank competition is somewhat mixed. There is evidence (Degryse and Ongena (2005)) that loan rates increase with detailed measures of distance between the firm and competing banks in Belgium and decrease with the distance between the firm and the lender. The effect of the number of bank branches is not statistically significant when added to the equation. Cross country evidence suggests that bank concentration decreases the likelihood of bank finance, with the impact decreasing in firm size (see Beck et al. (2004)). Bonaccorsi di Patti and Gobbi (2001) find that measures of concentration are positively and significantly associated with the quantity of credit going to small firms in local provincial markets in Italy, while the association with measures of entry is negative for all firms. Branch density exerts, instead, a positive effect on the credit flow to all firms. Bonaccorsi di Patti and Dell'Ariccia (2004) find that bank competition is less favorable to the emergence of new firms in sectors where informational asymmetries are greater.

All the arguments reviewed above about the effect of the evolution of the banking sector are likely to matter more for firms that are more dependent upon local finance, such as small firms. The effect on large firms, with access to financial intermediaries nationwide and to national and international securities markets, is likely to be more limited. Moreover, as suggested by Rajan and Zingales (1998), it is also likely that growth in the banking sector will matter more, in general, for firms in industries that are more dependent upon external financing for technological reasons, such as efficient scale of operations, requirement for continuing investment, etc. It is also possible that banking development and advances in information gathering and processing by intermediaries may have limited effects on more traditional, low-tech, and less dynamic sectors that banks had become more accustomed in evaluating, while they may have a greater impact in more high tech and dynamic sectors.

Finally, the effect of the evolution in the banking sector may differ between process and product innovations. Product innovation is likely to be a riskier and less collateralizable activity, consisting 
mainly in expenditures for human capital. Process innovations, instead, are frequently embodied or accompanied by the purchase of new equipment that can be used as collateral. As a result, banking development may have a limited effect on product innovation, requiring, instead, the emergence of intermediaries (such as venture capitalists) better suited to solve the severe asymmetric information and agency problems of such activity. Some authors have also argued that firms with arm's length borrowing will develop more breakthrough innovations than similar firms that rely on relationship based borrowing (see Atanassov et al. (2005)). The argument draws on the idea that relationship lending is less likely to promote new, unfamiliar technologies. Furthermore, a successful innovation may be subject to hold up and value expropriation in relationship financing.

\section{$3 \quad$ Data and Descriptive Statistics}

The data used in this paper come from two main sources. Provincial data on local financial development come from the Bank of Italy, whereas firm level data come from the surveys "Indagine sulle Imprese Manifatturiere" published every three years by Capitalia's Observatory of SMEs. In this section we first briefly describe the cross sectional dispersion of banking development in Italy and its evolution overtime in the 90 's. We then present some stylized facts on firms' innovative activity, using firm level data on product and process innovation and on $\mathrm{R} \& \mathrm{D}$. We also discuss the financing sources of fixed investment and of R\&D spending.

\subsection{Banking Development}

We will rely on branch density (number of branches divided by population) by province as a measure of the level of development of the local credit markets (see Table 1). The choice of this variable is motivated by two main reasons. Firstly, it is commonly used in the empirical literature on local banking development (see, for instance, Jayaratne and Strahan (1996) and Degryse and Ongena (2005)). Secondly, and possibly more importantly, it captures the dimension of banking development that is 
likely to be more heavily affected by the deregulation process. ${ }^{8}$ In fact, the mean and the median of branch density both display large increases during the 90's, with the median increasing from 0.361 in 1991 to 0.509 in the 1998-2000 period (see columns 2 through 5). These increases are made possible by the process of banking deregulation that has allowed geogrphical diversification of existing domestic actors in other local markets, starting from the second part of the 80 's. The density variable displays a large interprovincial dispersion, as measured by the standard deviation or the interquartile range. Moreover, the dispersion has been increasing with time. In the last column we describe the distribution of the rate of change of branch density between 2000 and 1991. The data show that there is dispersion in the level of banking development: the median rate of increase in branch density is $42.1 \%$, while the first and third quartiles are $29.1 \%$ and $55.7 \%$ respectively. For the period 1991-2000 as a whole, the data suggest that the between (provinces) variation is more important than the within (over time) variation.

In the last but one line of the table we report the correlation between branch density in the 90's and branch density in 1936, the year in which the Italian banking system was reorganized and regulation put in place that basically determined the structure of the banking market until the beginning of deregulation. The correlation between bank distribution in 1936 and in the nineties is rather large (above 0.628) and significant and has changed rather slowly over the years, although one notices a small decrease as time goes by. The correlation of the rate of increase during the 90's with the initial value is negative (and significant), suggesting that banking development was faster in provinces where the banking sector was initially less developed.

In Table 2 we report some descriptive statistics on bank density - as opposed to branch density measured as the number of banks operating in a province divided by population. There is geographical dispersion in the number of banks in each province. However, in sharp contrast with what we observe for branch density, both the mean and the median are fairly stable over time, with the mean (median)

\footnotetext{
${ }^{8}$ An additional advantage of this measure is that it is available on a homogeneous basis for long periods of time. Unfortunately, there are breaks in the series for total deposit or total loans by province, due to the reclassification of "Istituti di Credito Speciale". It is not possible, therefore, to rely on these two series to build alternative measures of banking development at the province level.
} 
increasing only from 0.065 (0.061) in 1991 to 0.068 (0.065) in the 1998-2000 period. Analogously, the dispersion - as measured by the standard deviation - is substantially unchanged. This confirms what has been found in other studies (Bonaccorsi di Patti and Gobbi (2001)), namely that the deregulation process has been followed by a nation-wide merger wave. In turn, this has reduced the number of banks at the national level but not at the provincial level because of a substantial increase in the geographical diversification of surviving banks. The near stability in the distribution characterizing the number of banks in each province makes it unlikely that there is enough within province variation in the data to allow us to identify the effect of changes in the number of banks over time.

Finally, the evolution of concentration in local credit markets, using the Herfindhal index, is described in Table 3. As in Table 2, the unit of observation is the bank and the market share of each bank is computed as the number of its branches over the total number of branches in the province. It provides a more refined picture compared to the simple number of banks since it takes into account the possibility of an uneven distribution of market shares within each province. The data basically confirm the evidence presented in Table 2. In particular the level of average concentration, measured by the mean or the median, was rather stable during our sample period, showing only a small decrease over time. Again, there is dispersion across provinces in the degree of concentration.

\subsection{Firms and Innovation}

The firm level information on innovation we use in this paper comes from the 6th, 7th and 8 th survey "Indagine sulle Imprese Manifatturiere" by Capitalia's Observatory of SMEs (OSMEs from now). ${ }^{9}$ The surveys, conducted in 1995, 1998, and 2001 on a sample of manufacturing firms, contain information on innovation activities for the previous three year periods (1994-1992, 1997-1995, and 2000-1998) and are supplemented by standard balance sheet data. In each wave the sample is selected (partly) with a stratified method for firms with up to 500 workers, whereas firms above this threshold are all

\footnotetext{
${ }^{9}$ The surveys are run by the "Osservatorio sulle Piccole e Medie Imprese" (Observatory over SMEs), an institution associated with Capitalia, an Italian bank. More detailed information about the surveys can be found at the web site www.capitalia.it.
} 
included. Strata are based on geographical area, industry, and firm size. It is not clear however, that the stratification criteria have remained constant over time. Moreover some firms are added to the sample outside the stratification criteria. This may explain why one observes a large decline in the average size of the firms included in the sample, which makes it impossible to use aggregate wave statistics to track the evolution of relevant variables at the economy level. Each survey contains respectively 4431, 4497, and 4680 manufacturing firms, although many of them do not provide complete information on some of the variables relevant to our research. For this reason we were forced to exclude from the sample firms with incomplete information or with extreme observations for the variables of interest. Details of the sample selection procedures are contained in the Data Appendix.

Table 4 summarizes information about the introduction of innovations by our sample of Italian firms and about the nature of the innovations. The first four rows report, separately for each wave, the frequencies of product innovations, of process innovations, of either a process or a product innovation, or of both. In the next two rows, the frequency of product (process) innovation is instead calculated conditional on having introduced a process (product) innovation. The last two rows report the probabilities of introducing a product (process) innovation conditional on performing $R \& D$ activity.

Some interesting stylized facts emerge. ${ }^{10}$ First, the descriptive statistics show that process innovation is more frequent than product innovation. Pooling the three waves, only $36.7 \%$ of firms declare to have introduced at least one product innovation. The share of firms introducing process innovation is instead higher $(58 \%)$.

Second, the probability of introducing a product innovation is higher for firms that have also introduced a process innovation in the same time period. This is not surprising since the introduction of a new product may well require a new production technique or at least the updating of an existing one. However, process innovation does not necessarily imply product innovation. In fact, conditional on having introduced a new process, only around $47 \%$ of firms introduce a new product over the three

\footnotetext{
${ }^{10}$ See Parisi et al. (2006) for an analysis of Italian firms' innovation activity and of its impact on productivity, using the $6^{\text {th }}$ and $7^{\text {th }}$ wave of the Capitalia's survey. Moreover, see Herrera and Minetti (2007) for an analysis of the effect of the length of the relationship with the main bank on innovation using the $8^{t h}$ wave of the Capitalia survey.
} 
waves.

Third, a large percentage of firms are not engaged in formal R\&D activity: more than half of the firms are characterized by zero R\&D spending in most periods. Fourth, the last two rows report the probabilities of introducing a product (process) innovation conditional on performing R\&D activity. As it can be seen, the conditional probabilities are higher than the corresponding unconditional probabilities for both types of innovations. This suggests that R\&D spending is positively correlated with both types of innovation. However, the share of firms introducing a process innovation is higher than the share of firms engaged in at least some R\&D activity. This suggests that there are other determinants of the probability of introducing a new process, besides the own R\&D conducted by the firm. For instance, new technologies may be embodied in the new capital goods purchased by the firm, in which case the firm avails itself of the technological improvements achieved in the domestic or foreign investment goods sectors.

Finally, the data imply an apparent decrease of the innovative activities of Italian firms, particularly in the 1998-2000 period. However, this is probably due to the fact that the nature of the sample has changed and smaller firms have received a greater weight, particularly in the last wave. For instance, the percentage of firms with less than 250 employees has increased from $84.33 \%$ in 1992-1994 to $87.64 \%$ in 1995-1997, to $93.25 \%$ in 1998-2000 (see Table A1). Similarly the average size of the total capital stock has decreased by approximately $24 \%$ between the first and second wave, and by almost $37 \%$ between the first and third wave of the survey (see last line of Table 4). Moreover, innovation activity and size are positively correlated for the firms in this sample, as shown in the econometric results of Section $4 .^{11}$

In Table 5 we provide some evidence on how investment in R\&D and in fixed capital is financed. Internal funds are the main source of financing both for fixed investment and R\&D spending. However, internal sources are even more important for R\&D, representing $81.6 \%$ of the total, versus $51.5 \%$ for fixed investment, using the figures for the three surveys taken together. Conversely, bank lending

\footnotetext{
${ }^{11}$ See also Parisi et al. (2006).
} 
is more important for fixed investment (22.4\%) than for R\&D spending (9.4\%). This might suggest that the development of the banking sector may be particularly important for fixed investment and, perhaps, for process innovation, if investment in new machinery is a key mechanism through which firms absorb process innovation. We cannot learn much from the evolution over time of the financing ratios, since they are affected by the changing nature of the sample and by the increasing presence of smaller firms, as we have already noted.

\section{Econometric Results: Probability Models for Process and Product Innovation}

In assessing the effect of local banking development on innovation, we will first model the probability of introducing product or process innovations as a function of local (provincial) financial development, measured by branch density. We will start by estimating logit models on the pooled data for a simple specification that includes also industry dummies, region dummies, wave dummies, and a set of firm level variables such as size, legal form (corporation or not), association with a business group or with a technology consortium.

We then augment this specification with provincial GDP, other province level variables that capture the availability of human capital, social capital, public infrastructure, quality of the court system, and potential for externalities and economies of scope. Alternatively, we include in the specification province dummies. The objective of the exercise is to control for provincial characteristics that may affect innovation and may be correlated with banking development.

Finally, we generalize the model by including firm level variables capturing $R \& D$ and fixed investment intensity. This recognizes the fact that the innovation process depends both on internal and external (to the firm) inputs and that banking development is just one of the determinants of the quantity of internal inputs. Moreover, it allows us to assess whether banking development has an effect once we control for the quantity of firm level inputs in the production of innovations. In Section 
5 we will, instead, evaluate the direct effect of banking development on $R \& D$ and investment. We also allow for the effect of branch density to differ across different types of firms, depending upon their size, need for external finance, or technological sophistication of the sector they are in. In all cases we provide tests on the possible endogeneity of branch density, using the procedure suggested by Rivers and Vuong (1988). Since the power of the test depends upon having correctly specified the model for branch density, we also estimate linear probability models by instrumental variables. Banking structure variables from 1936 are used as instruments for branch density, as in Guiso et al. (2004a). These instruments are time invariant, but they are allowed to have a different effect on branch density in each period.

Up to this point we have not controlled yet for unobserved time invariant firm level characteristics (of which provincial effects are just a subset). We do that by estimating conditional logit models. This addresses the endogeneity problems associated with a possible correlation between branch density (and fixed investment and R\&D intensity) with the time invariant components of the error term since the latter have been removed from the conditional likelihood. The drawback is that we now rely on a smaller sample for estimation, since only firms that appear in multiple surveys and switch across states contribute to the likelihood function. Moreover, the conditional logit model does not address the potential correlation between the idiosyncratic component of the error term, on the one hand, and branch density or $\mathrm{R} \& \mathrm{D}$ and fixed investment intensity, on the other. To tackle this issue we estimate a linear probability model for the firms that appear in at least two surveys using the system GMM estimator and employing as instruments appropriately lagged values of branch density, of firm investment, sales and cash flow. ${ }^{12}$

\subsection{Simple Pooled Logit Models}

We will first estimate a simple logit model separately for process innovations (see Table 6) and product innovations (see Table 7) on the pooled firm level data. Initially we control only for sector, region, time

${ }^{12}$ See Arellano and Bond (1991) and Blundell and Bond (1998). 
(wave) and a set of firm level variables such as size, age, legal form (corporation or not), association with a business group or with a technology consortium. In this specification we cannot distinguish whether banking development affects the quantity or the effectiveness of firm level inputs into the innovative process, and we can only capture its total effect. Moreover, we are implicitly assuming that the firm level inputs in the innovation production function are adequately captured by sector, region, time dummies, branch density and our firm level variables. Firm size is measured as the log of the capital stock (fixed capital plus R\&D capital) at the beginning of the first year of each wave. This means that our measure of size is predetermined relative to the innovation decision. We allow for both a linear and quadratic effect of age. In column 1 of Tables 6 and 7 our measure of banking development, branch density, is measured as the average number of branches per capita over the three year period covered by each wave. In column 2 we, instead, use the number of branches in the year preceding the three year period covered by each wave (1991 for 1992-1994, 1994 for 1995-1997, 1997 for 1998-2001). This reduces the potential risk of a spurious association between branch density and innovation due to the fact that a favorable shock in period $t$ specific to each province may lead to the opening of new branches. In the calculation of the standard errors we allow for heteroskedasticity and for spatial correlation between the error term for firms within the same province. This correlation may reflect the presence of province level unobservables that may affect the probability of introducing an innovation.

The results in columns 1 and 2 suggest that, independently from the timing of the branch density variable, the probability of introducing a process or product innovation is significantly and positively associated both with firm size and with the degree of banking development. The coefficient of the branch density variable is significant at the $1 \%$ level in the process innovation equation and at around the $5 \%$ level in the product innovation equation. ${ }^{13}$ Since the significance and size of the branch density coefficient is very similar regardless of whether its average value over the period or its lagged value

\footnotetext{
${ }^{13}$ Herrera and Minetti (2007) find instead that the measure of financial development proposed by Guiso et al. (2004a, $2004 \mathrm{~b}$ ) is not a significant determinant of product or process innovation, using the $8^{\text {th }}$ wave of the Capitalia survey. Their measure reflects the effect of regional dummies on the probability that households are credit constrained.
} 
is used, in the remaining logit specifications we concentrate on the results obtained using its average value. ${ }^{14}$ Branch density remains a very significant determinant of process innovation also when we introduce provincial GDP per capita (column 3) or a set of time invariant provincial controls including human capital, social capital, public infrastructure, the quality of the court system, and potential for externalities (column 4). The results for product innovation do not change with the introduction of provincial GDP, but the marginal significance of the banking development coefficient is reduced to around $10 \%$, when the set of provincial control variables detailed above is introduced. Note, however, that in all cases provincial GDP or the set of provincial controls are not jointly or individually significant. ${ }^{15}$

The coefficient of region and wave dummies are always jointly very significant in all the equations. Size is a significant determinant of both for process and product innovation with the probability of either type of innovation increasing with the size of the firm. These conclusions hold also if we use the number of employees or sales as a measure of size. Similarly, the conclusions regarding the significance and magnitude of the coefficient of branch density is robust to whatever measure of size is used. Age is a significant determinant of product, but not of process innovation: the probability of introducing a product innovation increases with age until the firm is 57 years of age and then it starts to decline. The coefficient of the corporate form dummy tends to be not significant, while the significance level of the business group or technology consortium dummies is between $6 \%$ and $8 \%$ for process innovation. Only belonging to a technology consortium matters somewhat for product innovation (with similar significance levels).

The effect of banking development is sizeable. For instance, going from the first quartile (0.305) to the third quartile (0.533) of branches per capita in the 1991-2000 period, the logit model in column 1 generates an approximate increase in the probability of introducing a process innovation of around

\footnotetext{
${ }^{14}$ Moreover, the endogeneity test that we will discuss later in section 4.3 is not suggestive of endogeneity problems for the average number of branches. Section 4.3 also contains IV estimates of the linear probability model.

${ }^{15}$ In both equations, all provincial controls are indeed very imprecisely estimated. The only partial exceptions are the "human capital" variable which (rather surprisingly) is found to be negative and significant at the $10 \%$ in the process innovation equation and the "social capital" variable which is positive - albeit significant only at the 13.6 significance level - in the product innovation equation. See the Data Appendix for details on the provincial controls.
} 
5.9 percentage points. The effect on the probability of product innovation resulting from this change is instead 4.5 percentage points.

The effect of banking development for either process or product innovation is not robust, however, to the introduction of provincial dummies in the equation (see column 5). This may reflect the fact that the between provinces variation in branch density is more important than the within province variation, so that, after controlling for province and wave dummies, it is difficult to pin down the branch density coefficient precisely. However, contrary to regional and industry dummies, the provincial dummies are not jointly significant in the equation for process innovation. This may reflect the fact that many of the potentially relevant unobserved factors are likely to have a stronger regional dimension, as opposed to a provincial dimension. ${ }^{16}$ We will revisit the issue of the robustness of the results to the inclusion of provincial dummies in the context of the more general model described in the next section.

\subsection{More General Logit Models with Fixed Investment and R\&D Intensity and Differential Response to Banking Development}

The positive association between branch density and the probability of an innovation in the specifications controlling for unobserved region effects and observed provincial factors is intriguing, but it would be premature to draw definitive conclusions, since the association is not significant when controlling for unobserved province effects, although the latter are not jointly significant themselves for process innovation.

In this section we will extend the model in two dimensions. First, we will include in the specification additional firm level variables that capture R\&D and fixed investment intensity (measured, respectively, as the average value of fixed $R \& D$ or fixed investment spending over total fixed and $R \& D$ capital). These variables can be thought as firm level inputs in the process that generates innovation. We have included fixed investment intensity, in addition to $R \& D$ intensity because, particularly for process

\footnotetext{
${ }^{16}$ The empirical evidence on firms' innovative activity (surveyed in Cohen, 1995) suggests that industry-level factors play a very important role whereas the impact of local-level factors (in our case, provincial-level) is unclear.
} 
innovation, new processes may be embodied in new machines. This, in principle, should allow us to assess whether the effect of banking development on innovation operates through its effect on the quantity of firm-level inputs in the innovation production function, or whether there is a quality effect that goes beyond that. In section 5 we will, instead examine the effect of financial development on the quantity of fixed investment and $\mathrm{R} \& \mathrm{D}$ spending.

Second, we will allow the effect of financial development to differ according to firm size, as one would expect, since small firms are more likely to be dependent upon local banks compared to larger firms. The effect of local banking development may also vary according to whether a firm is in more (less) high tech sectors or in sectors characterized by a different degree of dependence on external financing. The classification of sectors according to the nature of technology is derived from Parisi et al. (2006) and is reported in the Data Appendix. We continue to use the size of the total capital stock as a measure of size, and we rely on the proxy for financial dependence suggested by Rajan and Zingales (1998) and based on the percentage of external financing in the corresponding US sector.

The logit results in column (1) through (4) of Tables 8 and 9 are obtained allowing for industry, region, and wave effects and they suggest that branch density is a significant determinant of both product and process innovation, even after we control for fixed investment and R\&D intensity. ${ }^{17}$ Its coefficient is slightly larger than in the case in which the firm level variables are not included. This is somewhat puzzling since by including firm level inputs one would expect that the branch density variable should capture only the increase in the quality/effectiveness of these firm level inputs in generating an innovation. However the two coefficients are well within the $95 \%$ confidence interval of each one of them.

Interestingly, both fixed investment and $\mathrm{R} \& \mathrm{D}$ intensity are positively and significantly associated with the probability of introducing process or product innovation. The magnitude of the coefficient of fixed investment intensity is greater in the equation for process innovation compared to its value in the equation for product innovation. This is consistent with the idea that process innovations are

\footnotetext{
${ }^{17}$ Wave, industry, and regional dummies are included in all the specifications.
} 
embodied in new machines and that they are absorbed into the production process through fixed investment spending.

When we allow the coefficient of branch density to differ across firms, the response of process innovation to banking development is greater for firms in high-tech sectors compared to those in lowtech sectors. Moreover, it is significant for the former, but not for the latter sectors. However, the marginal significance level for the test on the hypothesis that the coefficients for high-tech and lowtech sectors are identical is $9.3 \%$. In addition, the coefficient of the interaction between the degree of external financial dependence and branch density is positive, as one would expect, but not significant. ${ }^{18}$ The one for the interaction between branch density and firm size is negative, as one would expect, but significant only at the $10 \%$ level. For product innovation there is no difference in response depending upon the technological nature of the sector or upon the degree of financial dependence. The effect of banking development on product innovation appears to be significantly greater for larger firms.

In the last four columns of Tables 8 and 9 we control for provincial dummies. They continue to be jointly not significant for process innovation, but not for product innovation. Interestingly, even allowing for province specific fixed effects, branch density continues to be significant at the $5 \%$ level for firms in the high-tech sector. Moreover, the interaction between branch density and the degree of financial dependence is almost significant at the $10 \%$ level. Considering together the main effect and the interaction term, the marginal significance level of the effect of banking development is around $8 \%$ at the $50^{\text {th }}$ percentile of the distribution for external financial development, $5 \%$ at the $75^{\text {th }}$ percentile, and $3 \%$ at the $90^{t h}$ percentile. The marginal significance level for banking development in the model that allows for an interaction for size is around $7 \%$ at the $25^{t h}$ percentile of the size distribution, $5 \%$ at the $10^{\text {th }}$ percentile, and $4 \%$ at the $5^{\text {th }}$ percentile. Summarizing, even after controlling for provincial dummies, there is evidence that local financial development matters for process innovation for firms in high-tech sectors, in sectors more dependent on external finance, and for smaller firms. The same cannot be said about product innovation (see columns (5) through (8) of Table 9). Only the

\footnotetext{
${ }^{18}$ Note that there is a degree of overlap between the technology and external financial dependence need, in the sense that many (but not all) of the more technologically advanced sectors also require more external finance.
} 
interaction between branches and size is significant (and positive), but the introduction of province dummies renders the total effect of branch density insignificant for all specifications and all types of firms.

Finally, as mentioned in section 3 , the degree of competition in the industry is also expected to affect the availability and the cost of bank credit and therefore firms' innovation decisions. In particular, existing theories point out that competition might have both a positive and a negative effect. For this reason we have estimated four sets of additional equations where different competition measures are separately included as additional explanatory variables to our basic models of columns (1) and (2). Our first two measures are the number of banks operating in a province and the provincial concentration level, as measured by the Herfindhal index. Alternatively, since it might be argued that concentration may be an inadequate measure of the competitive climate, we have also experimented with a direct mark-up measure constructed as the provincial spread between the interest rate on loans and the interest rate on deposits normalized by the latter. Finally, we have included as a control variable the rate of change in the number of branches per inhabitant. This variable is likely to be strongly positively associated with the entry of new players in each local banking market. In all specifications the coefficients of these variables are not significantly different from zero. Furthermore the sign and significance of the effect of the number of branches is not affected. ${ }^{19}$ We interpret this evidence more as providing a robustness check of the role played by our crucial variable (branch density) than as a full-fledged analysis of the role of bank competition on industrial innovation which clearly deserves a more in-depth analysis.

\subsection{Endogeneity of Banking Development: Testing and IV Estimation of Linear Probability Models}

There may be a concern that the branch density variable may be endogenous because its potential correlation with idiosyncratic province level components of the error term that also generate an increase

\footnotetext{
${ }^{19}$ Detailed results are available from the authors upon request.
} 
in the probability of an innovation, such as province specific technology or macro shocks not adequately controlled for by the province level GDP, time invariant provincial variables or wave dummies.

In order to address this issue one must identify a set of determinants of financial development (instruments) that are not correlated with the error term in the innovation equation. In our pooled cross sectional context we have followed the strategy in Guiso et al. (2004a, 2004b) and used as instruments variables that reflect the nature of the banking system in 1936, the year in which a fundamental reorganization of the banking system occurred and a set of rules and regulations were set in place that determined the structure of the banking system until the beginning of deregulation in the second half of the 80 's. More specifically the instruments used for the average level of branch density are the 1936 values of branches per inhabitant, the share of bank branches owned by local banks over total branches, the number of saving banks, and the number of cooperative banks per capita. Guiso et al. explain in details why these variables have predictive power for the level of banking development in the more recent past, but the basic idea is that different types of banks faced different constraints in opening new branches (national banks were more tightly regulated, and among local banks, cooperative banks faced tighter constraints). Moreover they argue that the way regions vary in their banking structure in 1936 is unrelated to the level of economic development at that time and that the differential treatment of different types of banks in the 1936 law were not driven by different regional economic factors, as opposed to political factors. Note that we use the provincial value of these variables, while Guiso et al. (2004a, 2004b), given the nature of their dependent variables, use their regional values.

We conduct two exercises. First, we follow Rivers and Vuong (1988) in testing for endogeneity. We first regress branch density on region, industry, wave dummies and the 1936 instruments (interacted with the wave dummies). We then add the residual of this equation to the innovation equations. The $\mathrm{t}$ statistic on its coefficient is a test of endogeneity for branch density and are reported at the bottom of all the Tables from 6 to $9 .{ }^{20}$ In all cases we cannot reject the hypothesis that the coefficient of the

\footnotetext{
${ }^{20}$ More specifically, we model the idiosyncratic component of the error term as $\varepsilon_{i j t}=\gamma u_{j t}+v_{i t}$ where $u_{j t}$ and $v_{i t}$ refer respectively to the province and the firm component of the idiosyncratic error. $u_{j t}$ can therefore be thought of as
} 
residuals equals zero and, therefore, there is no evidence of an endogeneity problem for branch density.

The conclusions we have reached so far concerning their significance also stand.

The power of the test depends upon having correctly specified the model for branch density. It is quite possible that bank structure variables in 1936, together with region and wave dummies may not adequately summarize the process generating branch density in the 1990 's. ${ }^{21}$ We also report, therefore, the results obtained when a linear probability model for process and product innovation is estimated by IV. The results for the specification including regional, wave, and industry dummies together with fixed investment and R\&D intensity are reported in Table 10 for both process and product innovation. For process innovation, the coefficient of branch density is strongly significant. Furthermore, the response of process innovation to banking development is greater, and significantly so, for firms in high-tech sectors compared to those in low-tech sectors. Finally, the interaction with the degree of external finance dependence is significant whereas the interaction with size is not. The effect of banking development is significant at the $5 \%$ level for firms at or above the $30^{\text {th }}$ percentile of the external financial dependence variable. For product innovation the coefficient of branch density is only significant at the $7.3 \%$ level, when it is not allowed to vary by firm size or sector. In addition, we do not find significant differences between high and low-tech sectors. The coefficient of the interaction between branch density and external finance dependence is also not significant, while the one with size is significant and positive. This result parallels the one obtained for the logit model with provincial dummies and seems to suggest that banking development allows only larger firms to overcome the information asymmetries associated with product innovation.

The Sargan test suggests that no major mis-specifications are present in the product or process equations, with the exception of the equation for process when the coefficient is not allowed to vary by

a province specific idiosyncratic shock to the technological frontier. $u_{j t}$ and $v_{i t}$ are assumed to be serially uncorrelated and independent of each other. We assume that $\varepsilon_{i j t}$ has a logistic distribution. $u_{j t}$ is defined to be the idiosyncratic shock in the equation that generates branch density, $z_{j t}$, i.e. $z_{j t}=\sum_{t=1}^{3} \beta_{t} \lambda_{t} x_{j t}+\lambda_{t}+\mu_{j}+u_{j t}$, where $x_{j t}$ is assumed to be independent of $v_{i t} . x_{j t}$ represents the 1936 instruments and $\lambda_{t}$ the wave dummies. The fitted residual from this last equation is then included as an additional regressor in the innovation equations.

${ }^{21}$ Note, in passing, that the consistency of the estimates obtained by the control function approach proposed by, among others, Rivers and Vuong (1988) depends upon the model for the endogenous variable being correctly specified. This requirement does not apply to the IV estimate of the linear probability model. 
size or sector (see column 1). The overall conclusion is that, even using instruments from the distant past still leaves the effect of branch density significant for process innovation for firms in high-tech sectors or in sectors more dependent upon external finance. Banking development has a less significant effect on product innovation.

\subsection{Controlling for Firm-Specific Effects: Conditional Logit Models and System GMM for Linear Probability Models}

In the previous section we have not exploited the temporal dimension of our panel to control for time-invariant firm level effects. In this section we will present results obtained when we control for unobserved firm characteristics (including, but not limited to provincial location) that are relatively constant through time by using an appropriate transformation that eliminates the time invariant effects. Conditional logit models allow us to do just that. Given the legitimate worries about the correlation between branch density, fixed investment and $R \& D$ intensity, and other firm level variables, on the one hand, and firm level unobserved characteristics that are relatively time invariant, on the other, this estimation strategy is very appealing. The drawback is that now one needs multiple observations on each firm and only switchers contribute to the likelihood function, while the largest fraction of our panel is made up of firms that are observed only at one point in time. Still, we are left with a sizeable sample of almost five hundred of observations on switchers for process innovation and almost four hundred observations for product innovation. Another problem is that endogeneity can arise not only because of the presence of a firm-specific time invariant effect but also because there might be a province-specific idiosyncratic shock to the technological frontier that leads to an increase in both the probability of observing an innovation and in the incentive for banks to open new branches. Moreover, fixed investment and R\&D intensity are likely to be correlated with the contemporaneous idiosyncratic component of the error term as well. We will address both these issues by estimating a linear probability model for firms that appear in at least two surveys by system GMM. 
Table 11 contains the conditional logit results for process innovation. ${ }^{22}$ The coefficient on average branch density is positive and significant at approximately the $5 \%$ with or without the intensity variables. Furthermore, the coefficient on branch density is significant (and larger) for firms in the high-tech sector, although the difference between high-tech and low-tech sectors is not statistically significant. The coefficient on the interaction with external financial dependence is also significant and positive at approximately the $5 \%$ level. ${ }^{23}$ For product innovation the parameter on branch density is always estimated very imprecisely, whether or not one includes R\&D and fixed investment intensity, and whether or not one allows the coefficient to differ across sectors or firms according to size (see Table 12).

Finally, in Table 13 we report the estimates obtained by applying the system GMM estimator to the linear probability model for process and product innovations to address the potential endogeneity of branch density, firm size and fixed investment and R\&D intensities. Recall that this estimator combines the orthogonality conditions of the model in differences with those for the model in levels. For the equation in differences the instrument set includes lagged values of branch density (column 1 and 6) or lagged values of branch density, of the sales and cash flow to capital ratios, and of the investment rate in fixed assets and in intangibles (columns (2) through (5) and (7) through (10)). ${ }^{24}$ For the equation in levels the difference of these variables are used as instruments. For process innovation, the coefficient of the branch variable is significant at the $9 \%$ level in the equation without fixed investment and R\&D intensity and at the $6.5 \%$ level in the specification including the intensity variables (which have been instrumented as well). Note that R\&D intensity coefficient is significant and the one for fixed investment intensity nearly so at conventional levels. Again the effect of branches is larger and strongly

\footnotetext{
${ }^{22}$ Some firm level variables do not appear in the specification either because they are time invariant or because they have been omitted due to their lack of significance or of impact on the results of interest.

${ }^{23}$ Again, the test proposed by Rivers and Vuong (1988) is not suggestive of endogeneity problems for branch density. Since the residuals generated using the 1936 instruments may exhibit limited time variation, we also model branch density as a function of lagged bank density and lagged provincial per capita GDP. We estimate this last equation on data averaged over three years non-overlapping intervals using the GMM-system estimator. The test results are very similar when we use the residuals obtained using this specifications (they are reported in Tables 11 and 12) or the one based on the 1936 instruments.

${ }^{24}$ As an example, for the difference between the third (2000-1998) wave and the second wave (1997-1995), values of the variables in 1994, 1993 and 1992 have been used as instruments.
} 
significant in the high-tech sectors, but not in the low-tech sectors. The coefficient of the interaction term with financial dependence is significant at the $5 \%$ level (and positive as expected). The Sargan test is not suggestive of mis-specification of the equation for process innovation. The GMM results for product innovation are not supportive of a significant role for banking development for the totality or firms or for any subset. More generally, none of the coefficients appear to be significant, with the exception of size.

\section{Econometric Results: Fixed Investment and R\&D Spending and Banking Development}

In many of the models estimated in the previous section we have included fixed and R\&D investment intensity as controls. In this case one gets closer to estimating the effect of banking development that goes beyond its effect on the quantity of R\&D and on fixed investment. Obviously, in order to assess the total effect of banking development on the probability of introducing an innovation, one must investigate whether financial development has an effect on fixed and R\&D investment spending, and this is the issue we will discuss in this section. Banking development may have an effect on spending mainly through a cost of capital effect or through a relaxation of financing constraints effect, or both.

\subsection{Fixed Investment Equations}

In this sub-section we present the results of simple fixed investment equations estimated on yearly data where our branch density variable is directly included in a model containing also the lagged dependent variable, output divided by total capital, and cash flow divided by total capital. To control for macro effects common to all firms we will include also year dummies, so that we will be able to pick up an effect of banking development only if the evolution over time of the cost of capital varies across provinces. In the more general specification, the cash flow sensitivity of investment will be allowed to vary by firm size or by technological intensity or dependence upon external finance of the sector that 
a firm belongs to. Moreover, the coefficient for each firm type will also be allowed to depend upon the degree of banking development. Also, we will recognize that our regressors will be correlated with the idiosyncratic component of the error term. We will use the GMM system estimator in which values lagged two or three times of output, cash flow, and branch density (or of the appropriate interactions) are used as instruments for the equation in differences and once lagged differences of the same variables as instruments for the equation in levels. In all cases, we will limit ourselves to firms that have at least six consecutive observations.

Our results are summarized in Table 14. Both the Sargan and the AR(2) test statistics do not signal major specification problems in most specifications. The latter is however a little on the low side in some columns (and particularly in columns 1-2 and 6). As expected, both the output to capital and the cash flow to capital ratios are positive and often significant. However, in our simpler specifications (from column 1 to column 4), the number of branches is mostly not significantly different from zero. ${ }^{25}$ One possible explanation is that after controlling for year dummies there is not enough variability in the branch density variable to pin down its coefficient precisely in this equation. Interestingly, in column (5) the coefficient on the cash flow variable is positive and significant and its interaction with branch density is negative and significant, thus suggesting that local financial development reduces the cash flow sensitivity of investment. Moreover, we have allowed the cash flow coefficient and its interaction with branch density to differ across firm size (column 8). After some experimentation, the sharper results are obtained when we allow the coefficients to differ between firms in the bottom three quartiles of the firm size distribution and firms in the top quartile. ${ }^{26}$ We now observe that the cash flow coefficient is significant (and larger) only for small firms. Furthermore the estimated parameters on the interaction between branch density and cash flow suggest that banking development reduces significantly the size of the cash flow coefficient only for small firms, as one would expect, since these firms are more dependent on local sources of finance. On the contrary, when we permit the effect to

\footnotetext{
${ }^{25}$ The coefficient is actually negative and significant when the cash flow and branch density coefficient is allowed to differ between small and large firms.

${ }^{26}$ Size is still measured by the total capital stock.
} 
differ according to the technological level (column 6) or the degree of external financial dependence (column 7) of the sectors, we do not find any significant effect.

\section{$5.2 \quad$ R\&D Investment Equations}

As we have already mentioned in section $3, \mathrm{R} \& \mathrm{D}$ spending is characterized by an empirical distribution with a mass probability at zero in our sample of firms. For this reason we have modelled the R\&D investment decision as a two stage process. In the first stage firms decide whether to invest in R\&D or not, whereas in the second stage the decision on the amount of the investment is taken, conditional on positive spending.

Table 15 reports the results for conditional logit estimates of the first stage where the binary decision is regressed against firm size as measured by total capital at the beginning of the period, the contemporaneous cash flow to total capital ratio, the lagged output to total capital ratio, and the number of branches. Since the output to capital ratio was never significant it has been excluded from the equations we report. We find that both the coefficient of cash flow and of the number of branches are positive and significantly different from zero in the basic specification reported in column 1 . When we allow the coefficients to be different according to the technological level of the sector (column 2), we find that the cash flow effect is much larger in size and significantly so for the sample of firms operating in high-tech sectors. The effect of cash flow and of the number of branches are found, instead, not to vary with the degree of financial dependence. Finally, when we split our sample according to firm size, we find a positive and significant relation between the number of branches and the probability of non zero R\&D spending only for small firms. The cash flow coefficient is significantly different from zero at conventional levels only for small firms, although the point estimate is greater for large firms (but not very precisely estimated). ${ }^{27}$ Also in this case we have performed an endogeneity test by including as an additional regressor the residuals from an equation that explains financial development as a function of its own lagged value and lagged values of provincial GDP. In all cases its coefficient is not significant,

\footnotetext{
${ }^{27}$ We have also experimented with including an interaction term between branches and cash flow, but its coefficient was not significant.
} 
suggesting that there is not an endogeneity problem deriving from the potential correlation between branch density and a province specific idiosyncratic component of the error term in the logit model.

Finally, for the firm/year observations characterized by positive R\&D spending, we have estimated by GMM a set of linear equations similar to the ones used for fixed investment. In all our specifications, financial development turns out to have no significant effect on the amount of R\&D spending. ${ }^{28}$ This happens to be the case independently of how we measure the dependent variable. In particular, we have experimented with the $R \& D$ to total capital ratio, the $R \& D$ to production ratio and the $\log$ of R\&D spending. More generally, the model does not seem to be well specified and the Sargan test statistics lead to the rejection of the instrument validity assumption in all specifications. ${ }^{29}$

\section{Conclusions}

What is the final verdict on the effect of local (provincial) banking development on innovation? There is clear evidence from pooled logit models of a positive and significant effect of banking development on the probability of introducing a process or product innovation, even after controlling for regional unobserved heterogeneity, observable time invariant provincial variables, and provincial per capita GDP. This result is robust to the inclusion of $R \& D$ and fixed investment spending in the equation. For process innovation, the effect is larger for firms in more high-tech sectors and, to a lesser extent, for smaller firms or for firms in sectors characterized by a greater need for external finance. For process innovation, moreover, the results for firms in high-tech sectors and in sectors more dependent upon external finance are robust to the inclusion of provincial dummies in the specification. The results for product innovation do not survive the addition of provincial dummies.

The conclusions for process innovation are largely robust to using the 1936 banking structure variables as instruments. The instrumental variables results for product innovation are, instead, less supportive of a significant effect of banking development. The results for process innovation are

\footnotetext{
${ }^{28}$ A similar result is obtained by Rotondi (2006) who estimates a standard R\&D equation augmented with the financial development variables introduced by Guiso et al. (2004a).

${ }^{29}$ To save on space we do not report these additional results which are available from the authors upon request.
} 
also largely robust to using only the information for the switchers in a conditional logit model that controls also for unobservable firm specific effects. Branch density remains a significant variable and its coefficient is larger for high-tech sectors and for sectors with a higher degree of dependence on external finance. The results for the GMM system estimator of the linear probability model for process innovation, in which both banking development and R\&D and fixed investment intensities are instrumented confirm those of the conditional logit model. We do not find any significant effect of banking development on product innovation in the conditional logit model or in the linear probability model estimated by GMM.

On the whole, there is strong evidence from a variety of the discrete choice models that banking development has a significant and important effect on process innovation. The evidence is much weaker and not robust for product innovation. Perhaps the degree of risk and low collateralizability of activities related to product innovation makes banking intermediaries not the ideal ones in its financing. In this case, it is probably necessary to rely on internal finance or on specialized sources such as venture capital with a greater degree of involvement with and control on firm's activities (Da Rin et al. (2006)). The low level of development of this type of intermediaries in Italy constitutes a potential impediment to the introduction of product innovation.

Finally, there is some evidence that banking development has lessened the severity of financing constraints faced by small firms when they invest in fixed capital. Small firms are indeed those that are likely to rely more heavily on local banks for their financing needs. Analogously, we also find that financial development affects the probability of carrying out R\&D especially for small firms. To the extent that investment in fixed and $R \& D$ capital are internal inputs in the innovation process, the effect of the relaxation for a subset of firms of financing constraints on fixed capital spending and on the probability of a positive $\mathrm{R} \& \mathrm{D}$ spending constitute additional channels through which banking development can affect innovation. 


\section{References}

[1] Alessandrini, P., Presbitero, A. and A. Zazzaro (2006), "Banks, Distances and Financing Constraints for Firms" Working Papers 266, Dipartimento di Economia, Università Politecnica delle Marche.

[2] Angelini P. and N. Cetorelli (2003), "Bank Competition and Regulatory Reform: The Case of the Italian Banking System", Journal of Money Credit and Banking, 35, 663-684.

[3] Arellano, M. and S. Bond (1991), "Some Tests of Specification for Panel Data: Monte Carlo Evidence and an Application to Employment Equations", Review of Economic Studies, 58, 277297.

[4] Atanassov, J., Nanda, V and A. Seru (2005), "Finance and innovation: the case of publicly traded firms", mimeo.

[5] Bandiera, O., Caprio, G., Honohan, P. and F. Schiantarelli (2000), "Does Financial Reform Raise or reduce Saving?", Review of Economics and Statistics, May, 239-263.

[6] Beck, T., A. Demirguc-Kunt, and V. Maksimovic (2004), "Bank Competition and access to finance: international evidence", Journal of Money, Credit and Banking, 36(3), 627-648.

[7] Beck, T., R. Levine, and N. Loayza (2000), "Finance and the Sources of Growth", Journal of Financial Economics, 58, 261-300.

[8] Bekaert, G., C.H. Harvey, and C. Lundblad (2005), "Does Financial Liberalization Spur Growth?", Journal of Financial Economics, 77, 3-55.

[9] Bencivenga, V. and Smith, B. (1991) "Financial Intermediation and endogeneous growth", Review of Economic Studies, 58(2), 195-209.

[10] Berger, A. N. and Udell, G. (2002), "Small business credit availability and relationship lending: the importance of bank organizational structure", The Economic Journal, 112, F32-F53.

[11] Black, S. E. and P. E. Strahan (2002), "Entrepreneurship and Bank Credit Availability", Journal of Finance, LVII(6), 2807-2832.

[12] Blundell R. W. and S. R Bond (1998), "Initial Conditions and Moment Restrictions in Dynamic Panel Data Models", Journal of Econometrics, 87, 115-143.

[13] Bofondi, M. and G. Gobbi (2006), "Informational Barriers to Entry into Credit Markets", Review of Finance, 10(1), 39-67.

[14] Bonacorsi di Patti, E. and G. Dell'Ariccia (2004), "Bank Competition and Firm Creation", Journal of Money, Credit and Banking, 36(2), 225-251.

[15] Bonacorsi di Patti, E. and G. Gobbi (2001), "The Changing Structure of Local Credit Markets: Are Small Businesses Special?", Journal of Banking and Finance, 25(12), 2209-2237.

[16] Boot A.W.A and Thakor (2000), "Can Relationship Banking Survive Competition?", Journal of Finance, LV(2), 679-713.

[17] Carpenter, R. E. and Petersen, B. C. (2002), "Capital Market Imperfections, High-tech Investment, and New Equity Financing", The Economic Journal, 112, F54-F72.

[18] Cetorelli, N. and P. E. Strahan (2006), "Finance as a Barrier to Entry: Bank Competition and Industry Structure in Local U.S. Markets", Journal of Finance, LXI(1), 437-461 
[19] Cohen, W. (1995), "Empirical studies of innovative activity", in Stoneman, P. (ed) Handbook of the Economics of Innovation and Technological Change, Blackwell.

[20] Da Rin, M., G. Nicodano and A. Sembenelli (2006), "Public Policy and the Creation of Active Venture Capital Markets", Journal of Public Economics, 90(8-9), 1699-1723

[21] Degryse, Hans A. and Ongena, Steven R. (2005), "Distance, Lending Relationships and Competition", Journal of Finance, LX(1), 231-266.

[22] Demirguc-Kunt, A. and V. Maksimovic (1998), "Law, Finance, and Firm Growth", Journal of Finance, LIII(6), 2107-2137.

[23] Galindo, A., F. Schiantarelli, and A. Weiss (2007), "Does Financial Liberalization improve the Allocation of Investment.? Micro Evidence from Developing Countries", Journal of Development Economics, 83, 562-587.

[24] Greenwood, J. and B. Jovanovic (1990), "Financial Development, Growth, and the Distribution of Income", Journal of Political Economy, 98, October, 1076-1107.

[25] Griliches, Z. (1979), "Issues in Assessing the Contribution of Research and Development to Productivity Growth", The Bell Journal of Economics, 10(1), 92-116.

[26] Guiso, L., Jappelli, T., Padula M. and M. Pagano (2004), "Financial Market Integration and economic growth in the EU", Economic Policy, 40, 523-577.

[27] Guiso, L., P. Sapienza and L. Zingales (2004a), "Does Local Financial Development Matter?", Quarterly Journal of Economics, vol. 119(3), 929-969.

[28] Guiso, L., P. Sapienza and L. Zingales (2004b), "The Cost of Banking Regulation", Proceedings, Federal Reserve Bank of Chicago, May, 125-164.

[29] Guiso, L., P. Sapienza and L. Zingales (2004c), "The Role of Social Capital in Financial Development", American Economic Review, 94(3), 526-556.

[30] Harrison, P, Sussman O. and Zeira, J. (2004): "Finance and growth: theory and new evidence", mimeo.

[31] Henry, P.B. (2000), "Do Stock Market Liberalizations Cause Investment Booms?", Journal of Financial Economics, 58(1-2), 301-334.

[32] Herrera, A.M., and R. Minetti (2007), "Informed Finance and Technological Change: Evidence from Credit Relationships", Journal of Financial Economics, 83(1), 223-269

[33] Jayaratne, J. and P. E. Strahan (1996), "The Finance-Growth Nexus: Evidence from Bank Branch Deregulation", Quarterly Journal of Economics, 111(3), 639-670.

[34] King, R. and Levine, R. (1993a), "Finance, Entrepreneurship and Growth: Theory and Evidence", Journal of Monetary Economics, 32, 513-542.

[35] King, R. and Levine, R. (1993b), "Finance and Growth: Schumpeter May Be Right", Quarterly Journal of Economics, 108(3), 717-737.

[36] Levine, R. (1997), "Financial Development and Economic Growth: Views and Agenda", Journal of Economic Literature, June, 688-726.

[37] Levine, R., Loayza, N. and T. Beck (2000), "Financial Intermediation and Growth: Causality and Causes", Journal of Monetary Economics, 46, 31-77. 
[38] Levine, R. and S. Zervos. (1998), "Stock market, Banks, and Economic Growth", American Economic Review, 88, 537-558.

[39] Parisi, M.L., Schiantarelli, F. and A. Sembenelli (2006), "Productivity, Innovation Creation and Absorption, and R\&D: Microeconometric Evidence for Italy", European Economic Review, 50, 2037-2061

[40] Petersen M. A., and R. G. Rajan (1995), "The Effect of Credit Market Competition on Lending Relationships", Quarterly Journal of Economics, 110(2), 407-443.

[41] Petersen M. A., and R. G. Rajan (2002), "Does Distance Still Matter: The Information Revolution in Small Business Lending", Journal of Finance, LVII(6), 2533-2570.

[42] Rajan, R. and L. Zingales, (1998), "Financial Dependence and Growth", American Economic Review, 88, 559-586.

[43] Rivers, D. and Q. Vuong (1988), "Limited Information Estimators and Exogeneity Testing for Simultaneous Probit Models", Journal of Econometrics, 39(3), 347-366.

[44] Rotondi, Z. (2006), "R\&D Expenditure, Comparative Localization of Banking Development and University-Industry Knowledge Spillovers", mimeo.

[45] Saint-Paul, G. (1992), "Technological Choice, Financial Markets and Economic Development", European Economic Review, 36(4), May, 763-781.

[46] Williamson, S.D. (1986), "Costly Monitoring, Financial Intermediation, and Equilibrium Credit Rationing", Journal of Monetary Economics, 18, 159-179.

[47] Williamson, S.D. (1987), "Costly Monitoring, Loan Contracts, and Equilibrium Credit Rationing", Quarterly Journal of Economics, 102, 135-145.

[48] Wurgler, J. (2000), "Financial Markets and the Allocation of Capital", Journal of Financial Economics, 58, 187-214. 
Table 1: Bank Branches to Population Ratio

\begin{tabular}{|c|c|c|c|c|c|c|c|}
\hline & (1) & $(2)$ & $(3)$ & $\overline{(4)}$ & 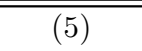 & $\overline{(6)}$ & $\overline{(7)}$ \\
\hline & 1936 & 1991 & 1992-94 & 1995-97 & 1998-00 & 1991-00 & $\Delta \% 00-91$ \\
\hline Observations & 91 & 91 & 91 & 91 & 91 & 910 & 91 \\
\hline Mean & 0.204 & 0.346 & 0.391 & 0.444 & 0.489 & 0.432 & 47.1 \\
\hline Standard Deviation & 0.109 & 0.123 & 0.131 & 0.155 & 0.164 & 0.156 & 34.5 \\
\hline - within &.. & .. & .. & .. & .. & 0.058 & .. \\
\hline - between & .. & .. & .. & .. & .. & 0.146 & .. \\
\hline First Quartile & 0.130 & 0.255 & 0.291 & 0.308 & 0.345 & 0.305 & 29.1 \\
\hline Median & 0.182 & 0.361 & 0.408 & 0.470 & 0.509 & 0.432 & 42.1 \\
\hline Third Quartile & 0.256 & 0.419 & 0.469 & 0.533 & 0.591 & 0.533 & 55.7 \\
\hline Correlation with 1936 &.. & $\begin{array}{l}0.679 \\
(0.00)\end{array}$ & $\begin{array}{l}0.664 \\
(0.00)\end{array}$ & $\begin{array}{l}0.641 \\
(0.00)\end{array}$ & $\begin{array}{l}0.628 \\
(0.00)\end{array}$ & .. & $\begin{array}{c}-0.168 \\
(0.11)\end{array}$ \\
\hline Correlation with 1991 & .. & .. & .. & .. & .. & .. & $\begin{array}{c}-0.310 \\
(0.00)\end{array}$ \\
\hline
\end{tabular}

Note: The ratio is constructed by dividing the number of branches in each province by population in thousands. Columns (3) to (5) refer to the three year period average ratio; column (6) refers to the pooled sample over the 1991-2000 period; column (7) refers to the percentage variation in the 1991-2000 period. Pvalues of the null hypothesis that the correlation coefficient is 0 in round brackets.

Table 2: Banks to Population ratio

\begin{tabular}{|c|c|c|c|c|}
\hline & 1991 & $\overline{1992-94}$ & 1995-97 & 1998-00 \\
\hline Observations & 91 & 91 & 91 & 91 \\
\hline Mean & 0.065 & 0.066 & 0.066 & 0.068 \\
\hline Standard Deviation & 0.034 & 0.033 & 0.032 & 0.032 \\
\hline First Quartile & 0.043 & 0.044 & 0.044 & 0.045 \\
\hline Median & 0.061 & 0.063 & 0.064 & 0.065 \\
\hline Third Quartile & 0.079 & 0.083 & 0.084 & 0.087 \\
\hline
\end{tabular}

Note: The ratio is constructed by dividing the number of banks in each province by population in thousands. Columns (2) to (4) refer to the three year period average ratio.

Table 3: Herfindhal Index for Banks

\begin{tabular}{|c|c|c|c|c|}
\hline & 1991 & 1992-94 & 1995-97 & $1998-00$ \\
\hline Observations & 91 & 91 & 91 & 91 \\
\hline Mean & 0.148 & 0.143 & 0.139 & 0.141 \\
\hline Standard Deviation & 0.066 & 0.063 & 0.058 & 0.078 \\
\hline First Quartile & 0.100 & 0.094 & 0.096 & 0.095 \\
\hline Median & 0.135 & 0.132 & 0.131 & 0.129 \\
\hline Third Quartile & 0.178 & 0.170 & 0.160 & 0.162 \\
\hline
\end{tabular}

Note: The Herfindhal Index is computed at provincial level.

Market shares for each bank are computed as the number of its branches over the total number of branches in a province. The index ranges from 0 (atomistic market) to 1 (fully concentrated market). 
Table 4: Share of Innovative Firms by Type of Innovation (\%)

\begin{tabular}{l|c|c|c|c}
\hline \hline \multicolumn{2}{c}{$\mathbf{1 9 9 2 - 9 4}$} & \multicolumn{1}{c}{$\mathbf{1 9 9 5 - 9 7}$} & \multicolumn{1}{c}{$\mathbf{1 9 9 8 - 0 0}$} & Total \\
\hline Observations & 2055 & 2088 & 1882 & 6025 \\
Process & 64.23 & 68.49 & 39.64 & 58.02 \\
Product & 49.00 & 34.34 & 25.72 & 36.65 \\
Process or Product & 75.67 & 75.72 & 48.72 & 67.27 \\
Process and Product & 35.57 & 27.11 & 16.63 & 27.40 \\
Process | Product & 76.66 & 78.94 & 64.67 & 74.77 \\
Product | Process & 58.48 & 39.58 & 41.96 & 47.23 \\
Share of Obs. with R\&D average $>0$ & 51.19 & 36.49 & 41.50 & 43.07 \\
Process | R\&D average $>0$ & 78.90 & 83.20 & 56.21 & 73.33 \\
Product | R\&D average $>0$ & 68.06 & 52.49 & 43.92 & 56.22 \\
Total Capital & 11.5 & 8.7 & 5.5 & 8.6 \\
\hline \hline
\end{tabular}

Note: Rows 6, 7, 9, and 10 refer to conditional frequencies. (R\&D average $>0$ ) counts all firms which invested in $R \& D$ in at least one year in the observed period. Total Capital includes fixed capital and R\&D capital and is in million Euros at 2000 prices.

Table 5: R\&D and fixed investment financing (\%)

\begin{tabular}{llrrrr}
\hline \hline & & $\mathbf{1 9 9 2 - 9 4}$ & $\mathbf{1 9 9 5 - 9 7}$ & $\mathbf{1 9 9 8 - 0 0}$ & Total \\
\hline Fixed investments & & & & \\
& Observations & 1844 & 1940 & 1755 & 5539 \\
& Shareholders' capital & 1.19 & 1.65 & 1.17 & 1.34 \\
& Internal funds & 60.69 & 47.78 & 45.89 & 51.48 \\
& Loans & 22.70 & 24.46 & 19.76 & 22.38 \\
& Public funds & 3.03 & 5.21 & 5.24 & 4.49 \\
& Tax incentives & 1.46 & 6.45 & 6.77 & 4.89 \\
& Leasing & 9.92 & 13.01 & 19.91 & 14.17 \\
& Other & 1.00 & 1.43 & 1.25 & 1.23 \\
\hline R\&D investments & Observations & 1050 & 760 & 764 & 2574 \\
& Shareholders' capital & 1.60 & 1.41 & 1.09 & 1.39 \\
& Internal funds & 83.78 & 82.44 & 77.90 & 81.64 \\
& Loans & 10.46 & 8.92 & 8.55 & 9.44 \\
& Public funds & 2.58 & 3.51 & 5.64 & 3.76 \\
& Tax incentives & 0.85 & 1.63 & 4.74 & 2.23 \\
& Other & 0.72 & 2.09 & 2.09 & 1.53 \\
\hline \hline
\end{tabular}


Table 6: Basic Logit Models for Process Innovation

\begin{tabular}{|c|c|c|c|c|c|}
\hline & 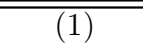 & 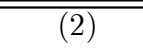 & 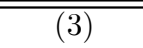 & 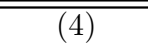 & 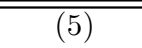 \\
\hline Number of firms & 6025 & 6025 & 6025 & 6025 & 6008 \\
\hline Estimation method & Logit & Logit & Logit & Logit & Logit \\
\hline Dependent variable & Process & Process & Process & Process & Process \\
\hline$(\text { Branches })_{j t}$ & $\begin{array}{l}1.065 \\
(0.006) \\
{[0.258]}\end{array}$ & $\begin{array}{c}. . \\
1.028\end{array}$ & $\begin{array}{l}1.097 \\
(0.004) \\
{[0.266]}\end{array}$ & $\begin{array}{l}1.191 \\
(0.001) \\
{[0.288]}\end{array}$ & $\begin{array}{c}2.107 \\
(0.134) \\
{[0.501]}\end{array}$ \\
\hline$(\text { Branches })_{j t-1}$ & .. & $\begin{array}{l}(0.010) \\
{[0.249]}\end{array}$ & .. & .. & .. \\
\hline$(\text { Firm Size })_{i t}$ & $\begin{array}{c}0.247 \\
(0.000)\end{array}$ & $\begin{array}{c}0.247 \\
(0.000)\end{array}$ & $\begin{array}{c}0.246 \\
(0.000)\end{array}$ & $\begin{array}{c}0.245 \\
(0.000)\end{array}$ & $\begin{array}{c}0.243 \\
(0.000)\end{array}$ \\
\hline$(\text { Age })_{i t}$ & $\begin{array}{l}-0.005 \\
(0.179)\end{array}$ & $\begin{array}{l}-0.005 \\
(0.179)\end{array}$ & $\begin{array}{l}-0.005 \\
(0.169)\end{array}$ & $\begin{array}{l}-0.005 \\
(0.208)\end{array}$ & $\begin{array}{l}-0.005 \\
(0.198)\end{array}$ \\
\hline$(\text { Age-squared })_{i t}$ & $\begin{array}{c}0.003 \\
(0.477)\end{array}$ & $\begin{array}{c}0.003 \\
(0.478)\end{array}$ & $\begin{array}{c}0.003 \\
(0.472)\end{array}$ & $\begin{array}{c}0.002 \\
(0.502)\end{array}$ & $\begin{array}{c}0.002 \\
(0.523)\end{array}$ \\
\hline$(\text { Group })_{i t}$ & $\begin{array}{c}0.114 \\
(0.075)\end{array}$ & $\begin{array}{c}0.115 \\
(0.075)\end{array}$ & $\begin{array}{c}0.111 \\
(0.084)\end{array}$ & $\begin{array}{c}0.118 \\
(0.069)\end{array}$ & $\begin{array}{c}0.125 \\
(0.074)\end{array}$ \\
\hline$(\text { Corporation })_{i t}$ & $\begin{array}{c}0.201 \\
(0.340)\end{array}$ & $\begin{array}{c}0.195 \\
(0.356)\end{array}$ & $\begin{array}{c}0.195 \\
(0.354)\end{array}$ & $\begin{array}{c}0.199 \\
(0.346)\end{array}$ & $\begin{array}{c}0.229 \\
(0.224)\end{array}$ \\
\hline$(\mathrm{R} \& \mathrm{D} \text { consortium })_{i t}$ & $\begin{array}{c}0.663 \\
(0.074)\end{array}$ & $\begin{array}{c}0.662 \\
(0.074)\end{array}$ & $\begin{array}{c}0.661 \\
(0.074)\end{array}$ & $\begin{array}{c}0.660 \\
(0.075)\end{array}$ & $\begin{array}{c}0.693 \\
(0.064)\end{array}$ \\
\hline Pseudo $R^{2}$ & 0.082 & 0.082 & 0.082 & 0.082 & 0.090 \\
\hline Endogeneity test: Branches & {$[0.29]$} & {$[0.55]$} & {$[0.48]$} & {$[0.28]$} & {$[0.39]$} \\
\hline Industry dummies & $\operatorname{Yes}(0.00)$ & $\operatorname{Yes}(0.00)$ & $\operatorname{Yes}(0.00)$ & $\operatorname{Yes}(0.00)$ & $\operatorname{Yes}(0.00)$ \\
\hline Regional dummies & $\operatorname{Yes}(0.00)$ & $\operatorname{Yes}(0.00)$ & $\operatorname{Yes}(0.00)$ & $\operatorname{Yes}(0.00)$ & No \\
\hline Provincial GDP & No & No & $\operatorname{Yes}(0.22)$ & No & No \\
\hline Provincial controls & No & No & No & $\operatorname{Yes}(0.21)$ & No \\
\hline Provincial dummies & No & No & No & No & $\operatorname{Yes}(0.62)$ \\
\hline
\end{tabular}

\footnotetext{
Note: (Branches) $)_{j-1}$ is branch density the year preceding the three year period covered by each wave. The coefficient on Age-squared is multiplied by 100. All regressions include a constant and two wave dummies. Standard errors in columns from 1 to 4 are robust to within province heteroskedasticity whereas standard errors in column 5 are robust to heteroskedasticity of unknown form. P-values of the null that each coefficient (or each set of coefficients) is equal to 0 in round brackets. Marginal effects computed at the sample means of the explanatory variables in square brackets below the coefficients. Endogeneity test reports the p-value of the Rivers-Vuong test on the endogeneity of branches.
} 
Table 7: Basic Logit Models for Product Innovation

\begin{tabular}{|c|c|c|c|c|c|}
\hline & 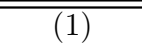 & 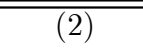 & 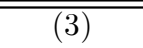 & 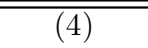 & 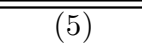 \\
\hline Number of firms & 6025 & 6025 & 6025 & 6025 & 5997 \\
\hline Estimation method & Logit & Logit & Logit & Logit & Logit \\
\hline Dependent variable & Product & Product & Product & Product & Product \\
\hline$(\text { Branches })_{j t}$ & $\begin{array}{c}0.877 \\
(0.045) \\
{[0.200]}\end{array}$ & .. & $\begin{array}{c}0.884 \\
(0.042) \\
{[0.201]}\end{array}$ & $\begin{array}{c}0.697 \\
(0.105) \\
{[0.159]}\end{array}$ & $\begin{array}{c}-1.485 \\
(0.306) \\
{[-0.338]}\end{array}$ \\
\hline$(\text { Branches })_{j t-1}$ & .. & $\begin{array}{l}(0.035) \\
{[0.214]}\end{array}$ & .. & .. & .. \\
\hline$(\text { Firm Size })_{i t}$ & $\begin{array}{c}0.273 \\
(0.000)\end{array}$ & $\begin{array}{c}0.273 \\
(0.000)\end{array}$ & $\begin{array}{c}0.273 \\
(0.000)\end{array}$ & $\begin{array}{c}0.273 \\
(0.000)\end{array}$ & $\begin{array}{c}0.274 \\
(0.000)\end{array}$ \\
\hline$(\text { Age })_{i t}$ & $\begin{array}{c}0.012 \\
(0.004)\end{array}$ & $\begin{array}{c}0.012 \\
(0.004)\end{array}$ & $\begin{array}{c}0.012 \\
(0.004)\end{array}$ & $\begin{array}{c}0.012 \\
(0.005)\end{array}$ & $\begin{array}{c}0.012 \\
(0.002)\end{array}$ \\
\hline$(\text { Age-squared })_{i t}$ & $\begin{array}{l}-0.011 \\
(0.008)\end{array}$ & $\begin{array}{l}-0.011 \\
(0.008)\end{array}$ & $\begin{array}{l}-0.011 \\
(0.008)\end{array}$ & $\begin{array}{l}-0.011 \\
(0.009)\end{array}$ & $\begin{array}{l}-0.010 \\
(0.008)\end{array}$ \\
\hline$(\text { Group })_{i t}$ & $\begin{array}{l}-0.010 \\
(0.883)\end{array}$ & $\begin{array}{l}-0.009 \\
(0.891)\end{array}$ & $\begin{array}{l}-0.011 \\
(0.877)\end{array}$ & $\begin{array}{l}-0.007 \\
(0.914)\end{array}$ & $\begin{array}{l}-0.002 \\
(0.983)\end{array}$ \\
\hline$(\text { Corporation })_{i t}$ & $\begin{array}{c}0.256 \\
(0.192)\end{array}$ & $\begin{array}{c}0.251 \\
(0.198)\end{array}$ & $\begin{array}{c}0.255 \\
(0.192)\end{array}$ & $\begin{array}{c}0.251 \\
(0.200)\end{array}$ & $\begin{array}{c}0.281 \\
(0.184)\end{array}$ \\
\hline$(\mathrm{R} \& \mathrm{D} \text { consortium })_{i t}$ & $\begin{array}{c}0.621 \\
(0.064)\end{array}$ & $\begin{array}{c}0.620 \\
(0.064)\end{array}$ & $\begin{array}{c}0.621 \\
(0.064)\end{array}$ & $\begin{array}{c}0.643 \\
(0.057)\end{array}$ & $\begin{array}{c}0.626 \\
(0.051)\end{array}$ \\
\hline Pseudo $R^{2}$ & 0.089 & 0.089 & 0.089 & 0.089 & 0.095 \\
\hline Endogeneity test: Branches & {$[0.46]$} & {$[0.92]$} & {$[0.40]$} & {$[0.89]$} & {$[0.50]$} \\
\hline Industry dummies & $\operatorname{Yes}(0.00)$ & $\operatorname{Yes}(0.00)$ & $\operatorname{Yes}(0.00)$ & $\operatorname{Yes}(0.00)$ & $\operatorname{Yes}(0.00)$ \\
\hline Regional dummies & $\operatorname{Yes}(0.00)$ & $\operatorname{Yes}(0.00)$ & $\operatorname{Yes}(0.00)$ & $\operatorname{Yes}(0.00)$ & No \\
\hline Provincial GDP & No & No & $\operatorname{Yes}(0.81)$ & No & No \\
\hline Provincial controls & No & No & No & $\operatorname{Yes}(0.50)$ & No \\
\hline Provincial dummies & No & No & No & No & $\operatorname{Yes}(0.00)$ \\
\hline
\end{tabular}

Note: as in Table 6 
Table 8: Logit Models for Process Innovation with Firm-Level Variables

\begin{tabular}{|c|c|c|c|c|c|c|c|c|}
\hline & 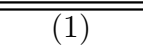 & 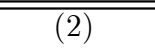 & 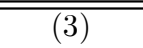 & 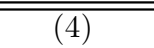 & 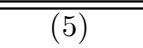 & 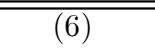 & 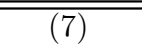 & 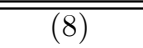 \\
\hline Number of firms & 6025 & 6025 & 6025 & 6025 & 6008 & 6008 & 6008 & 6008 \\
\hline Estimation method & Logit & Logit & Logit & Logit & Logit & Logit & Logit & Logit \\
\hline Dependent variable & Process & Process & Process & Process & Process & Process & Process & Process \\
\hline$(\text { Branches })_{j t}$ & $\begin{array}{c}1.421 \\
(0.000) \\
{[0.342]}\end{array}$ &.. & $\begin{array}{c}1.052 \\
(0.028)\end{array}$ & $\begin{array}{c}3.520 \\
(0.007)\end{array}$ & $\begin{array}{c}2.529 \\
(0.078) \\
{[0.596]}\end{array}$ &.. & $\begin{array}{c}2.177 \\
(0.133)\end{array}$ & $\begin{array}{c}4.675 \\
(0.013)\end{array}$ \\
\hline$(\text { High-Tech })_{i t}(\text { Branches })_{j t}$ & .. & $\begin{array}{c}1.978 \\
(0.000) \\
{[0.477]}\end{array}$ & .. & .. & .. & $\begin{array}{c}3.172 \\
(0.035) \\
{[0.764]}\end{array}$ &.. & .. \\
\hline$(\text { Low-Tech })_{i t}(\text { Branches })_{j t}$ & .. & $\begin{array}{c}1.162 \\
(0.007) \\
{[0.280]}\end{array}$ & .. & .. &.. & $\begin{array}{c}2.334 \\
(0.105) \\
{[0.562]}\end{array}$ &.. & .. \\
\hline$(\text { Fin. dep. })_{i t}(\text { Branches })_{j t}$ & .. &.. & $\begin{array}{c}1.373 \\
(0.114)\end{array}$ &.. & .. & $\cdot$. & $\begin{array}{l}1.500 \\
(0.102)\end{array}$ & .. \\
\hline$(\text { Size })_{i t}(\text { Branches })_{j t}$ & .. &.. & .. & $\begin{array}{l}-0.286 \\
(0.096)\end{array}$ & .. & .. & .. & $\begin{array}{l}-0.320 \\
(0.084)\end{array}$ \\
\hline$(\text { Firm Size })_{i t}$ & $\begin{array}{c}0.338 \\
(0.000)\end{array}$ & $\begin{array}{c}0.339 \\
(0.000)\end{array}$ & $\begin{array}{c}0.338 \\
(0.000)\end{array}$ & $\begin{array}{c}0.477 \\
(0.000)\end{array}$ & $\begin{array}{c}0.334 \\
(0.000)\end{array}$ & $\begin{array}{c}0.334 \\
(0.000)\end{array}$ & $\begin{array}{c}0.334 \\
(0.000)\end{array}$ & $\begin{array}{c}0.490 \\
(0.000)\end{array}$ \\
\hline$(\text { Inv. Int. })_{i t}$ & $\begin{array}{c}2.745 \\
(0.000)\end{array}$ & $\begin{array}{c}2.747 \\
(0.000)\end{array}$ & $\begin{array}{c}2.747 \\
(0.000)\end{array}$ & $\begin{array}{c}2.736 \\
(0.000)\end{array}$ & $\begin{array}{c}2.733 \\
(0.000)\end{array}$ & $\begin{array}{c}2.735 \\
(0.000)\end{array}$ & $\begin{array}{c}2.736 \\
(0.000)\end{array}$ & $\begin{array}{c}2.722 \\
(0.000)\end{array}$ \\
\hline$(\mathrm{R} \& \mathrm{D} \text { Int. })_{i t}$ & $\begin{array}{l}8.890 \\
(0.000)\end{array}$ & $\begin{array}{c}8.890 \\
(0.000)\end{array}$ & $\begin{array}{c}8.873 \\
(0.000)\end{array}$ & $\begin{array}{c}8.900 \\
(0.000)\end{array}$ & $\begin{array}{c}9.250 \\
(0.000)\end{array}$ & $\begin{array}{c}9.242 \\
(0.000)\end{array}$ & $\begin{array}{c}9.233 \\
(0.000)\end{array}$ & $\begin{array}{c}9.253 \\
(0.000)\end{array}$ \\
\hline$(\text { Age })_{i t}$ & $\begin{array}{l}-0.004 \\
(0.237)\end{array}$ & $\begin{array}{l}-0.004 \\
(0.238)\end{array}$ & $\begin{array}{l}-0.004 \\
(0.234)\end{array}$ & $\begin{array}{l}-0.004 \\
(0.253)\end{array}$ & $\begin{array}{l}-0.004 \\
(0.310)\end{array}$ & $\begin{array}{l}-0.004 \\
(0.310)\end{array}$ & $\begin{array}{l}-0.004 \\
(0.311)\end{array}$ & $\begin{array}{l}-0.004 \\
(0.344)\end{array}$ \\
\hline$(\text { Age-squared })_{i t}$ & $\begin{array}{c}0.003 \\
(0.439)\end{array}$ & $\begin{array}{c}0.003 \\
(0.445)\end{array}$ & $\begin{array}{c}0.003 \\
(0.430)\end{array}$ & $\begin{array}{c}0.003 \\
(0.472)\end{array}$ & $\begin{array}{c}0.002 \\
(0.540)\end{array}$ & $\begin{array}{c}0.002 \\
(0.546)\end{array}$ & $\begin{array}{c}0.002 \\
(0.535)\end{array}$ & $\begin{array}{c}0.002 \\
(0.596)\end{array}$ \\
\hline$(\text { Group })_{i t}$ & $\begin{array}{c}0.003 \\
(0.958)\end{array}$ & $\begin{array}{c}0.005 \\
(0.942)\end{array}$ & $\begin{array}{c}0.007 \\
(0.919)\end{array}$ & $\begin{array}{c}0.003 \\
(0.959)\end{array}$ & $\begin{array}{c}0.013 \\
(0.853)\end{array}$ & $\begin{array}{c}0.015 \\
(0.838)\end{array}$ & $\begin{array}{c}0.017 \\
(0.818)\end{array}$ & $\begin{array}{c}0.013 \\
(0.856)\end{array}$ \\
\hline$(\text { Corporation })_{i t}$ & $\begin{array}{c}0.112 \\
(0.580)\end{array}$ & $\begin{array}{c}0.104 \\
(0.608)\end{array}$ & $\begin{array}{c}0.097 \\
(0.663)\end{array}$ & $\begin{array}{c}0.094 \\
(0.645)\end{array}$ & $\begin{array}{c}0.149 \\
(0.434)\end{array}$ & $\begin{array}{c}0.139 \\
(0.467)\end{array}$ & $\begin{array}{c}0.132 \\
(0.489)\end{array}$ & $\begin{array}{c}0.129 \\
(0.500)\end{array}$ \\
\hline$(\mathrm{R} \& \mathrm{D} \text { consortium })_{i t}$ & $\begin{array}{c}0.499 \\
(0.186)\end{array}$ & $\begin{array}{c}0.499 \\
(0.187)\end{array}$ & $\begin{array}{c}0.496 \\
(0.191)\end{array}$ & $\begin{array}{c}0.485 \\
(0.200)\end{array}$ & $\begin{array}{c}0.527 \\
(0.165)\end{array}$ & $\begin{array}{c}0.526 \\
(0.165)\end{array}$ & $\begin{array}{c}0.522 \\
(0.169)\end{array}$ & $\begin{array}{c}0.515 \\
(0.177)\end{array}$ \\
\hline Pseudo $R^{2}$ & 0.127 & 0.127 & 0.127 & 0.127 & 0.135 & 0.135 & 0.135 & 0.135 \\
\hline Endogeneity test: Branches & {$[0.40]$} & {$[0.66]$} & {$[0.10]$} & {$[0.25]$} & {$[0.43]$} & {$[0.73]$} & {$[0.31]$} & {$[0.52]$} \\
\hline Industry dummies & $\operatorname{Yes}(0.00)$ & $\operatorname{Yes}(0.00)$ & $\operatorname{Yes}(0.00)$ & $\operatorname{Yes}(0.00)$ & $\operatorname{Yes}(0.00)$ & $\operatorname{Yes}(0.00)$ & $\operatorname{Yes}(0.00)$ & $\operatorname{Yes}(0.00)$ \\
\hline Regional dummies & Yes $(0.00)$ & $\operatorname{Yes}(0.00)$ & $\operatorname{Yes}(0.00)$ & $\operatorname{Yes}(0.00)$ & No & No & No & No \\
\hline Provincial dummies & No & No & No & No & $\operatorname{Yes}(0.20)$ & $\operatorname{Yes}(0.20)$ & $\operatorname{Yes}(0.20)$ & $\operatorname{Yes}(0.19)$ \\
\hline Wald high vs low-tech & .. & $(0.093)$ &.. &.. &.. & $(0.128)$ &.. &. \\
\hline
\end{tabular}

Note:All regressions include a constant and two wave dummies. The coefficient on Age-squared is multiplied by 100. Standard errors in columns 1 to 4 are robust to within province heteroskedasticity whereas standard errors in columns 5 to 8 are robust to heteroskedasticity of unknown form. Marginal effects computed at the mean of the explanatory variable in square brackets. P-values in round brackets. Endogeneity test reports the p-value of the Rivers-Vuong test on the endogeneity of branches. 
Table 9: Logit Models for Product Innovation with Firm-Level Variables

\begin{tabular}{|c|c|c|c|c|c|c|c|c|}
\hline & 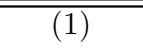 & $\overline{(2)}$ & 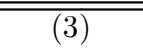 & 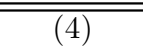 & 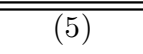 & 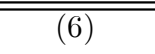 & 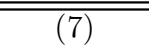 & $\overline{(8)}$ \\
\hline Number of firms & 6025 & 6025 & 6025 & 6025 & 5997 & 5997 & 5997 & 5997 \\
\hline Estimation method & Logit & Logit & Logit & Logit & Logit & Logit & Logit & Logit \\
\hline Dependent variable & Product & Product & Product & Product & Product & Product & Product & Product \\
\hline$(\text { Branches })_{j t}$ & $\begin{array}{c}1.172 \\
(0.009) \\
{[0.266]}\end{array}$ & $\cdot$. & $\begin{array}{c}1.323 \\
(0.007)\end{array}$ & $\begin{array}{l}-2.746 \\
(0.025)\end{array}$ & $\begin{array}{c}-1.377 \\
(0.349) \\
{[-0.312]}\end{array}$ & .. & $\begin{array}{l}-1.296 \\
(0.384)\end{array}$ & $\begin{array}{l}-5.126 \\
(0.007)\end{array}$ \\
\hline$(\text { High-Tech })_{i t}(\text { Branches })_{j t}$ & .. & $\begin{array}{c}1.273 \\
(0.006) \\
{[0.289]}\end{array}$ & .. & .. & {$\left[\begin{array}{lll}1 & -1 & -1\end{array}\right.$} & $\begin{array}{c}-1.160 \\
(0.445) \\
{[-0.263]}\end{array}$ & .. & .. \\
\hline$(\text { Low-Tech })_{i t}(\text { Branches })_{j t}$ & .. & $\begin{array}{c}1.117 \\
(0.027) \\
{[0.254]}\end{array}$ & .. & .. & .. & $\begin{array}{l}-1.465 \\
(0.321) \\
{[-0.333]}\end{array}$ & .. &.. \\
\hline$(\text { Fin. dep. })_{i t}(\text { Branches })_{j t}$ & .. &.. & $\begin{array}{l}-0.511 \\
(0.523)\end{array}$ & .. & .. & .. & $\begin{array}{l}-0.288 \\
(0.758)\end{array}$ & .. \\
\hline$(\text { Size })_{i t}(\text { Branches })_{j t}$ &.. & .. &.. & $\begin{array}{c}0.519 \\
(0.001)\end{array}$ & .. & .. &.. & $\begin{array}{c}0.548 \\
(0.002)\end{array}$ \\
\hline$(\text { Firm Size })_{i t}$ & $\begin{array}{c}0.286 \\
(0.000)\end{array}$ & $\begin{array}{c}0.286 \\
(0.000)\end{array}$ & $\begin{array}{c}0.286 \\
(0.000)\end{array}$ & $\begin{array}{c}0.036 \\
(0.625)\end{array}$ & $\begin{array}{c}0.283 \\
(0.000)\end{array}$ & $\begin{array}{c}0.283 \\
(0.000)\end{array}$ & $\begin{array}{c}0.283 \\
(0.000)\end{array}$ & $\begin{array}{c}0.018 \\
(0.835)\end{array}$ \\
\hline$(\text { Inv. Int. })_{i t}$ & $\begin{array}{c}0.643 \\
(0.000)\end{array}$ & $\begin{array}{c}0.643 \\
(0.000)\end{array}$ & $\begin{array}{c}0.642 \\
(0.000)\end{array}$ & $\begin{array}{c}0.651 \\
(0.000)\end{array}$ & $\begin{array}{c}0.587 \\
(0.001)\end{array}$ & $\begin{array}{c}0.589 \\
(0.001)\end{array}$ & $\begin{array}{c}0.587 \\
(0.001)\end{array}$ & $\begin{array}{c}0.597 \\
(0.001)\end{array}$ \\
\hline$(\mathrm{R} \& \mathrm{D} \text { Int. })_{i t}$ & $\begin{array}{c}9.841 \\
(0.000)\end{array}$ & $\begin{array}{c}9.840 \\
(0.000)\end{array}$ & $\begin{array}{c}9.847 \\
(0.000)\end{array}$ & $\begin{array}{c}9.870 \\
(0.000)\end{array}$ & $\begin{array}{l}10.004 \\
(0.000)\end{array}$ & $\begin{array}{l}10.004 \\
(0.000)\end{array}$ & $\begin{array}{l}10.008 \\
(0.000)\end{array}$ & $\begin{array}{l}10.029 \\
(0.000)\end{array}$ \\
\hline$(\text { Age })_{i t}$ & $\begin{array}{c}0.013 \\
(0.001)\end{array}$ & $\begin{array}{c}0.013 \\
(0.001)\end{array}$ & $\begin{array}{c}0.013 \\
(0.001)\end{array}$ & $\begin{array}{c}0.013 \\
(0.001)\end{array}$ & $\begin{array}{c}0.013 \\
(0.001)\end{array}$ & $\begin{array}{c}0.013 \\
(0.001)\end{array}$ & $\begin{array}{c}0.013 \\
(0.001)\end{array}$ & $\begin{array}{c}0.013 \\
(0.001)\end{array}$ \\
\hline$(\text { Age-squared })_{i t}$ & $\begin{array}{l}-0.011 \\
(0.004)\end{array}$ & $\begin{array}{l}-0.011 \\
(0.004)\end{array}$ & $\begin{array}{l}-0.011 \\
(0.004)\end{array}$ & $\begin{array}{l}-0.011 \\
(0.005)\end{array}$ & $\begin{array}{l}-0.011 \\
(0.005)\end{array}$ & $\begin{array}{l}-0.011 \\
(0.005)\end{array}$ & $\begin{array}{l}-0.011 \\
(0.006)\end{array}$ & $\begin{array}{l}-0.011 \\
(0.008)\end{array}$ \\
\hline$(\text { Group })_{i t}$ & $\begin{array}{l}-0.057 \\
(0.418)\end{array}$ & $\begin{array}{l}-0.057 \\
(0.420)\end{array}$ & $\begin{array}{l}-0.059 \\
(0.405)\end{array}$ & $\begin{array}{l}-0.056 \\
(0.433)\end{array}$ & $\begin{array}{l}-0.042 \\
(0.559)\end{array}$ & $\begin{array}{l}-0.042 \\
(0.564)\end{array}$ & $\begin{array}{l}-0.043 \\
(0.554)\end{array}$ & $\begin{array}{l}-0.041 \\
(0.572)\end{array}$ \\
\hline$(\text { Corporation })_{i t}$ & $\begin{array}{c}0.169 \\
(0.395)\end{array}$ & $\begin{array}{c}0.167 \\
(0.399)\end{array}$ & $\begin{array}{c}0.175 \\
(0.380)\end{array}$ & $\begin{array}{c}0.204 \\
(0.314)\end{array}$ & $\begin{array}{c}0.196 \\
(0.361)\end{array}$ & $\begin{array}{c}0.192 \\
(0.371)\end{array}$ & $\begin{array}{c}0.200 \\
(0.353)\end{array}$ & $\begin{array}{c}0.235 \\
(0.275)\end{array}$ \\
\hline$(\mathrm{R} \& \mathrm{D} \text { consortium })_{i t}$ & $\begin{array}{c}0.459 \\
(0.196)\end{array}$ & $\begin{array}{c}0.459 \\
(0.195)\end{array}$ & $\begin{array}{c}0.460 \\
(0.196)\end{array}$ & $\begin{array}{c}0.490 \\
(0.155)\end{array}$ & $\begin{array}{c}0.459 \\
(0.189)\end{array}$ & $\begin{array}{c}0.458 \\
(0.189)\end{array}$ & $\begin{array}{c}0.460 \\
(0.188)\end{array}$ & $\begin{array}{c}0.488 \\
(0.156)\end{array}$ \\
\hline Pseudo $R^{2}$ & 0.114 & 0.114 & 0.114 & 0.115 & 0.119 & 0.119 & 0.119 & 0.121 \\
\hline Endogeneity test: Branches & {$[0.20]$} & {$[0.39]$} & {$[0.26]$} & {$[0.37]$} & {$[0.41]$} & {$[0.71]$} & {$[0.46]$} & {$[0.51]$} \\
\hline Industry dummies & $\operatorname{Yes}(0.00)$ & $\operatorname{Yes}(0.00)$ & $\operatorname{Yes}(0.00)$ & $\operatorname{Yes}(0.00)$ & $\operatorname{Yes}(0.00)$ & $\operatorname{Yes}(0.00)$ & $\operatorname{Yes}(0.00)$ & $\operatorname{Yes}(0.00)$ \\
\hline Regional dummies & Yes $(0.00)$ & $\operatorname{Yes}(0.00)$ & $\operatorname{Yes}(0.00)$ & $\operatorname{Yes}(0.00)$ & No & No & No & No \\
\hline Provincial dummies & No & No & No & No & $\operatorname{Yes}(0.00)$ & $\operatorname{Yes}(0.00)$ & $\operatorname{Yes}(0.00)$ & $\operatorname{Yes}(0.00)$ \\
\hline Wald high vs low-tech &.. & $(0.681)$ &. & .. & .. & $(0.567)$ &.. & .. \\
\hline
\end{tabular}


Table 10: IV Linear Probability Models for Product and Process Innovation

\begin{tabular}{|c|c|c|c|c|c|c|c|c|}
\hline & $\overline{(1)}$ & 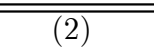 & 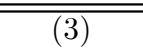 & $\overline{(4)}$ & 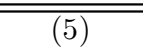 & 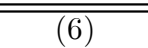 & $\overline{(7)}$ & $\overline{(8)}$ \\
\hline Number of firms & 6025 & 6025 & 6025 & 6025 & 6025 & 6025 & 6025 & 6025 \\
\hline Estimation method & $\begin{array}{c}\text { IV } \\
\text { Lin Pr. }\end{array}$ & $\begin{array}{c}\text { IV } \\
\text { Lin Pr. }\end{array}$ & $\begin{array}{c}\text { IV } \\
\text { Lin Pr. }\end{array}$ & $\begin{array}{c}\text { IV } \\
\text { Lin Pr. }\end{array}$ & $\begin{array}{c}\text { IV } \\
\text { Lin Pr. }\end{array}$ & $\begin{array}{c}\text { IV } \\
\text { Lin Pr. }\end{array}$ & $\begin{array}{c}\text { IV } \\
\text { Lin Pr. }\end{array}$ & $\begin{array}{c}\text { IV } \\
\text { Lin Pr. }\end{array}$ \\
\hline Dependent variable & Process & Process & Process & Process & Product & Product & Product & Product \\
\hline$(\text { High-Tech })_{i t}(\text { Branches })_{j t}$ & .. & $\begin{array}{c}0.578 \\
(0.000)\end{array}$ & .. & .. & .. & $\begin{array}{c}0.316 \\
(0.087)\end{array}$ & .. & \\
\hline$(\text { Low-Tech })_{i t}(\text { Branches })_{j t}$ & .. & $\begin{array}{c}0.258 \\
(0.113)\end{array}$ & .. & .. & .. & $\begin{array}{c}0.333 \\
(0.050)\end{array}$ & .. & .. \\
\hline$(\text { Fin. dep. })_{i t}(\text { Branches })_{j t}$ & .. &.. & $\begin{array}{c}0.519 \\
(0.012)\end{array}$ & .. & .. & (0.000) & $\begin{array}{l}-0.092 \\
(0.616)\end{array}$ & 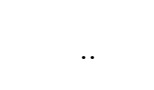 \\
\hline$(\text { Inv. Int. })_{i t}$ & $\begin{array}{c}0.546 \\
(0.000)\end{array}$ & $\begin{array}{c}0.548 \\
(0.000)\end{array}$ & $\begin{array}{c}0.547 \\
(0.000)\end{array}$ & $\begin{array}{c}0.545 \\
(0.000)\end{array}$ & $\begin{array}{c}0.124 \\
(0.000)\end{array}$ & $\begin{array}{c}0.124 \\
(0.000)\end{array}$ & $\begin{array}{c}0.124 \\
(0.000)\end{array}$ & $\begin{array}{c}0.127 \\
(0.000)\end{array}$ \\
\hline$(\mathrm{R} \& \mathrm{D} \text { Int. })_{i t}$ & $\begin{array}{l}1.706 \\
(0.000)\end{array}$ & $\begin{array}{l}1.709 \\
(0.000)\end{array}$ & $\begin{array}{c}1.701 \\
(0.000)\end{array}$ & $\begin{array}{l}1.710 \\
(0.000)\end{array}$ & $\begin{array}{c}2.113 \\
(0.000)\end{array}$ & $\begin{array}{c}2.115 \\
(0.000)\end{array}$ & $\begin{array}{c}2.112 \\
(0.000)\end{array}$ & $\begin{array}{c}2.111 \\
(0.000)\end{array}$ \\
\hline$(\text { Age })_{i t}$ & $\begin{array}{r}-0.001 \\
(0.288)\end{array}$ & $\begin{array}{l}-0.001 \\
(0.295)\end{array}$ & $\begin{array}{l}-0.001 \\
(0.285)\end{array}$ & $\begin{array}{l}-0.001 \\
(0.313)\end{array}$ & $\begin{array}{c}0.003 \\
(0.001)\end{array}$ & $\begin{array}{c}0.003 \\
(0.001)\end{array}$ & $\begin{array}{c}0.003 \\
(0.001)\end{array}$ & $\begin{array}{c}0.002 \\
(0.001)\end{array}$ \\
\hline$(\text { Age-squared })_{i t}$ & $\begin{array}{c}0.000 \\
(0.497)\end{array}$ & $\begin{array}{c}0.000 \\
(0.512)\end{array}$ & $\begin{array}{c}0.001 \\
(0.481)\end{array}$ & $\begin{array}{c}0.000 \\
(0.531)\end{array}$ & $\begin{array}{l}-0.002 \\
(0.002)\end{array}$ & $\begin{array}{l}-0.002 \\
(0.002)\end{array}$ & $\begin{array}{l}-0.002 \\
(0.002)\end{array}$ & $\begin{array}{l}-0.002 \\
(0.004)\end{array}$ \\
\hline$(\text { Group })_{i t}$ & $\begin{array}{c}0.001 \\
(0.963)\end{array}$ & $\begin{array}{c}0.001 \\
(0.930)\end{array}$ & $\begin{array}{c}0.002 \\
(0.889)\end{array}$ & $\begin{array}{c}0.000 \\
(0.975)\end{array}$ & $\begin{array}{l}-0.008 \\
(0.598)\end{array}$ & $\begin{array}{l}-0.008 \\
(0.598)\end{array}$ & $\begin{array}{l}-0.008 \\
(0.584)\end{array}$ & $\begin{array}{l}-0.007 \\
(0.626)\end{array}$ \\
\hline$(\text { Corporation })_{i t}$ & $\begin{array}{c}0.027 \\
(0.536)\end{array}$ & $\begin{array}{c}0.024 \\
(0.581)\end{array}$ & $\begin{array}{c}0.021 \\
(0.625)\end{array}$ & $\begin{array}{c}0.025 \\
(0.570)\end{array}$ & $\begin{array}{c}0.032 \\
(0.365)\end{array}$ & $\begin{array}{c}0.032 \\
(0.357)\end{array}$ & $\begin{array}{c}0.032 \\
(0.360)\end{array}$ & $\begin{array}{c}0.040 \\
(0.267)\end{array}$ \\
\hline
\end{tabular}

Note: All regressions include a constant and two wave dummies. The coefficient on Age-squared is multiplied by 100. Standard errors are robust to heteroskedasticity of unknown form. The instrument set includes the 1936 values of branches per inhabitant, the share of bank branches owned by local banks over total branches, the number of saving banks, and the number of cooperative banks per capita, all interacted with wave dummies. Marginal effects computed at the mean of the explanatory variables in square brackets. P-values in round brackets. Sargan is a test of the validity of overidentifying orthogonality conditions. 
Table 11: Conditional Logit Models for Process Innovation

\begin{tabular}{|c|c|c|c|c|c|}
\hline & $\overline{(1)}$ & $\overline{(2)}$ & $(3)$ & $\overline{(4)}$ & $(5)$ \\
\hline Number of firms & 469 & 469 & 469 & 469 & 469 \\
\hline Number of observations & 1017 & 1017 & 1017 & 1017 & 1017 \\
\hline Estimation method & $\begin{array}{l}\text { Cond. } \\
\text { Logit }\end{array}$ & $\begin{array}{l}\text { Cond. } \\
\text { Logit }\end{array}$ & $\begin{array}{l}\text { Cond. } \\
\text { Logit }\end{array}$ & $\begin{array}{l}\text { Cond. } \\
\text { Logit }\end{array}$ & $\begin{array}{l}\text { Cond. } \\
\text { Logit }\end{array}$ \\
\hline Dependent variable & Process & Process & Process & Process & Process \\
\hline$(\text { Firm Size })_{i t}$ & $\begin{array}{r}-0.484 \\
(0.048)\end{array}$ & $\begin{array}{l}-0.010 \\
(0.976)\end{array}$ & $\begin{array}{l}-0.000 \\
(0.999)\end{array}$ & $\begin{array}{c}-0.059 \\
(0.855)\end{array}$ & $\begin{array}{c}0.043 \\
(0.938)\end{array}$ \\
\hline$(\text { Branches })_{j t}$ & $\begin{array}{c}7.401 \\
(0.026)\end{array}$ & $\begin{array}{c}6.576 \\
(0.053)\end{array}$ & . & $\begin{array}{c}3.472 \\
(0.361)\end{array}$ & $\begin{array}{c}7.486 \\
(0.375)\end{array}$ \\
\hline$(\text { High-Tech })_{i t}(\text { Branches })_{j t}$ & .. & .. & $\begin{array}{c}8.583 \\
(0.021)\end{array}$ & .. & .. \\
\hline$(\text { Low-Tech })_{i t}(\text { Branches })_{j t}$ &.. & .. & $\begin{array}{c}5.142 \\
(0.150)\end{array}$ & .. & .. \\
\hline$(\text { Fin. dep. })_{i t}(\text { Branches })_{j t}$ & .. & .. & .. & $\begin{array}{l}10.069 \\
(0.053)\end{array}$ & \\
\hline$(\text { Size })_{i t}(\text { Branches })_{j t}$ & .. & .. & .. & & $\begin{array}{l}-0.108 \\
(0.906)\end{array}$ \\
\hline$(\text { Inv. Int. })_{i t}$ & .. & $\begin{array}{c}1.559 \\
(0.031)\end{array}$ & $\begin{array}{c}1.508 \\
(0.037)\end{array}$ & $\begin{array}{c}1.471 \\
(0.043)\end{array}$ & $\begin{array}{c}1.554 \\
(0.032)\end{array}$ \\
\hline$(\mathrm{R} \& \mathrm{D} \text { Int. })_{i t}$ & .. & $\begin{array}{c}10.045 \\
(0.000)\end{array}$ & $\begin{array}{l}10.302 \\
(0.000)\end{array}$ & $\begin{array}{l}10.153 \\
(0.000)\end{array}$ & $\begin{array}{c}10.024 \\
(0.000)\end{array}$ \\
\hline Endogeneity test: Branches & {$[0.99]$} & {$[0.97]$} & {$[0.56]$} & {$[0.82]$} & {$[0.12]$} \\
\hline Wald high vs low-tech & .. & .. & $(0.173)$ & .. &.. \\
\hline
\end{tabular}

Note: All regressions include two wave dummies. P-values in round brackets. Endogeneity test reports the p-value of the Rivers-Vuong test on the endogeneity of branches. 
Table 12: Conditional Logit Models for Product Innovation

\begin{tabular}{|c|c|c|c|c|c|}
\hline & $\overline{(1)}$ & $\overline{(2)}$ & $\overline{(3)}$ & $\overline{(4)}$ & 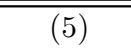 \\
\hline Number of firms & 398 & 398 & 398 & 398 & 398 \\
\hline Number of observations & 867 & 867 & 867 & 867 & 867 \\
\hline Estimation method & $\begin{array}{l}\text { Cond. } \\
\text { Logit }\end{array}$ & $\begin{array}{l}\text { Cond. } \\
\text { Logit }\end{array}$ & $\begin{array}{l}\text { Cond. } \\
\text { Logit }\end{array}$ & $\begin{array}{l}\text { Cond. } \\
\text { Logit }\end{array}$ & $\begin{array}{l}\text { Cond. } \\
\text { Logit }\end{array}$ \\
\hline Dependent variable & Product & Product & Product & Product & Product \\
\hline$(\text { Firm Size })_{i t}$ & $\begin{array}{l}-0.202 \\
(0.356)\end{array}$ & $\begin{array}{c}0.424 \\
(0.171)\end{array}$ & $\begin{array}{c}0.418 \\
(0.179)\end{array}$ & $\begin{array}{c}0.417 \\
(0.178)\end{array}$ & $\begin{array}{l}-0.121 \\
(0.811)\end{array}$ \\
\hline$(\text { Branches })_{j t}$ & $\begin{array}{c}0.437 \\
(0.893)\end{array}$ & $\begin{array}{c}0.241 \\
(0.942)\end{array}$ & $x^{2}+2+$ & $\begin{array}{l}-0.414 \\
(0.909)\end{array}$ & $\begin{array}{l}-9.361 \\
(0.231)\end{array}$ \\
\hline$(\text { High-Tech })_{i t}(\text { Branches })_{j t}$ & .. & .. & $\begin{array}{l}-1.736 \\
(0.638)\end{array}$ & .. & .. \\
\hline$(\text { Low-Tech })_{i t}(\text { Branches })_{j t}$ &.. & .. & $\begin{array}{l}1.198 \\
(0.724)\end{array}$ & .. & .. \\
\hline$(\text { Fin. dep. })_{i t}(\text { Branches })_{j t}$ & .. & .. & $\cdot$. & $\begin{array}{c}2.049 \\
(0.655)\end{array}$ & .. \\
\hline$(\text { Size })_{i t}(\text { Branches })_{j t}$ & .. & .. & .. & .. & $\begin{array}{c}1.122 \\
(0.175)\end{array}$ \\
\hline$(\text { Inv. Int. })_{i t}$ & .. & $\begin{array}{c}2.207 \\
(0.004)\end{array}$ & $\begin{array}{c}2.234 \\
(0.004)\end{array}$ & $\begin{array}{c}2.193 \\
(0.004)\end{array}$ & $\begin{array}{c}2.238 \\
(0.003)\end{array}$ \\
\hline$(\mathrm{R} \& \mathrm{D} \text { Int. })_{i t}$ & .. & $\begin{array}{c}3.810 \\
(0.104)\end{array}$ & $\begin{array}{c}3.766 \\
(0.108)\end{array}$ & $\begin{array}{c}3.855 \\
(0.100)\end{array}$ & $\begin{array}{c}4.053 \\
(0.086)\end{array}$ \\
\hline Endogeneity test: Branches & {$[0.73]$} & {$[0.74]$} & {$[0.92]$} & {$[0.29]$} & {$[0.75]$} \\
\hline Wald high vs low-tech &.. & .. & $(0.228)$ &.. &.. \\
\hline
\end{tabular}


Table 13: GMM Linear Probability Models for Process and Product Innovation

\begin{tabular}{|c|c|c|c|c|c|c|c|c|c|c|}
\hline & 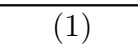 & $(2)$ & 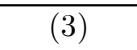 & $(\overline{(4)}$ & $(5)$ & (6) & (7) & 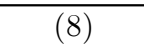 & (9) & (10) \\
\hline Number of firms & 899 & 899 & 899 & 899 & 899 & 899 & 899 & 899 & 899 & 899 \\
\hline Number of observations & 1934 & 1934 & 1934 & 1934 & 1934 & 1934 & 1934 & 1934 & 1934 & 1934 \\
\hline Estimation method & $\begin{array}{c}\text { GMM } \\
\text { Sys }\end{array}$ & $\begin{array}{c}\text { GMM } \\
\text { Sys }\end{array}$ & $\begin{array}{c}\text { GMM } \\
\text { Sys }\end{array}$ & $\begin{array}{c}\text { GMM } \\
\text { Sys }\end{array}$ & $\begin{array}{l}\text { GMM } \\
\text { Sys }\end{array}$ & $\begin{array}{l}\text { GMM } \\
\text { Sys }\end{array}$ & $\begin{array}{c}\text { GMM } \\
\text { Sys }\end{array}$ & $\begin{array}{l}\text { GMM } \\
\text { Sys }\end{array}$ & $\begin{array}{c}\text { GMM } \\
\text { Sys }\end{array}$ & $\begin{array}{c}\text { GMM } \\
\text { Sys }\end{array}$ \\
\hline Dependent variable & Process & Process & Process & Process & Process & Product & Product & Product & Product & Product \\
\hline$(\text { Firm Size })_{i t}$ & $\begin{array}{c}0.054 \\
(0.000)\end{array}$ & $\begin{array}{c}0.065 \\
(0.032)\end{array}$ & $\begin{array}{c}0.063 \\
(0.029)\end{array}$ & $\begin{array}{c}0.070 \\
(0.018)\end{array}$ & $\begin{array}{c}0.031 \\
(0.702)\end{array}$ & $\begin{array}{c}0.051 \\
(0.000)\end{array}$ & $\begin{array}{c}0.184 \\
(0.000)\end{array}$ & $\begin{array}{c}0.162 \\
(0.000)\end{array}$ & $\begin{array}{c}0.165 \\
(0.000)\end{array}$ & $\begin{array}{c}0.009 \\
(0.918)\end{array}$ \\
\hline$(\text { Branches })_{j t}$ & $\begin{array}{c}0.857 \\
(0.067)\end{array}$ & $\begin{array}{c}0.850 \\
(0.065)\end{array}$ & $(80-0)$ & $\begin{array}{c}0.486 \\
(0.337)\end{array}$ & $\begin{array}{c}0.348 \\
(0.793)\end{array}$ & $\begin{array}{c}0.373 \\
(0.446)\end{array}$ & $\begin{array}{c}0.530 \\
(0.328)\end{array}$ & th & $\begin{array}{c}0.397 \\
(0.479)\end{array}$ & $\begin{array}{l}-1.188 \\
(0.427)\end{array}$ \\
\hline$(\text { High-Tech })_{i t}(\text { Branches })_{j t}$ & ( & 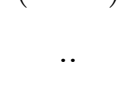 & $\begin{array}{c}1.130 \\
(0.017)\end{array}$ & ( & 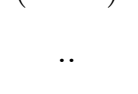 & (1) & (1) & $\begin{array}{c}0.858 \\
(0.120)\end{array}$ & 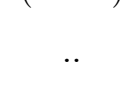 & ( \\
\hline$(\text { Low-Tech })_{i t}(\text { Branches })_{j t}$ & .. & .. & $\begin{array}{c}0.525 \\
(0.282)\end{array}$ & .. & .. & .. & .. & $\begin{array}{c}0.507 \\
(0.353)\end{array}$ & .. & .. \\
\hline$(\text { Fin. dep. })_{i t}(\text { Branches })_{j t}$ & .. & .. & .. & $\begin{array}{l}1.459 \\
(0.030)\end{array}$ & .. & .. & .. & .. & $\begin{array}{c}0.671 \\
(0.362)\end{array}$ & 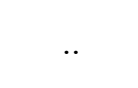 \\
\hline$(\text { Size })_{i t}(\text { Branches })_{j t}$ & .. & .. & .. & .. & $\begin{array}{c}0.065 \\
(0.674)\end{array}$ & .. & .. & .. & .. & $\begin{array}{c}0.204 \\
(0.235)\end{array}$ \\
\hline$(\text { Inv. Int. })_{i t}$ & .. & $\begin{array}{c}0.609 \\
(0.077)\end{array}$ & $\begin{array}{c}0.516 \\
(0.110)\end{array}$ & $\begin{array}{c}0.667 \\
(0.046)\end{array}$ & $\begin{array}{c}0.566 \\
(0.033)\end{array}$ & .. & $\begin{array}{c}0.713 \\
(0.067)\end{array}$ & $\begin{array}{c}0.374 \\
(0.287)\end{array}$ & $\begin{array}{c}0.440 \\
(0.231)\end{array}$ & $\begin{array}{c}0.498 \\
(0.076)\end{array}$ \\
\hline$(\mathrm{R} \& \mathrm{D} \text { Int. })_{i t}$ & .. & $\begin{array}{c}2.550 \\
(0.052)\end{array}$ & $\begin{array}{c}2.368 \\
(0.043)\end{array}$ & $\begin{array}{c}2.622 \\
(0.030)\end{array}$ & $\begin{array}{c}2.522 \\
(0.048)\end{array}$ & .. & $\begin{array}{c}0.074 \\
(0.960)\end{array}$ & $\begin{array}{c}1.491 \\
(0.246)\end{array}$ & $\begin{array}{c}1.981 \\
(0.132)\end{array}$ & $\begin{array}{l}-0.342 \\
(0.808)\end{array}$ \\
\hline Wald high vs low-tech & .. & .. & $(0.095)$ &. & .. & 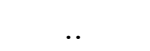 & .. & $(0.388)$ & .. & .. \\
\hline Sargan & $(0.499)$ & $(0.248)$ & $(0.418)$ & $(0.380)$ & $(0.521)$ & $(0.000)$ & $(0.259)$ & $(0.221)$ & $(0.246)$ & $(0.120)$ \\
\hline $\operatorname{AR}(1)$ & $(0.000)$ & $(0.000)$ & $(0.000)$ & $(0.000)$ & $(0.000)$ & $(0.000)$ & $(0.000)$ & $(0.000)$ & $(0.000)$ & $(0.000)$ \\
\hline
\end{tabular}

Note: Results are obtained with the one step GMM System estimator with robust standard errors. Instrument sets in columns (1) and (6) include only lagged branches, whereas instrument sets in columns (2) to (5) and (7) to (10) also include lagged values of cash flow intensity, of production intensity, and of fixed and intangible capital investiment intensities. All equations include wave, industry and regional dummies as regressors and instruments. P-values is round brackets. Sargan is a Sargan test of the validity of the overidentifying orthogonality conditions. AR(1) tests the presence of first order serial correlation in the transformed error. 
Table 14: Fixed Investments Equations

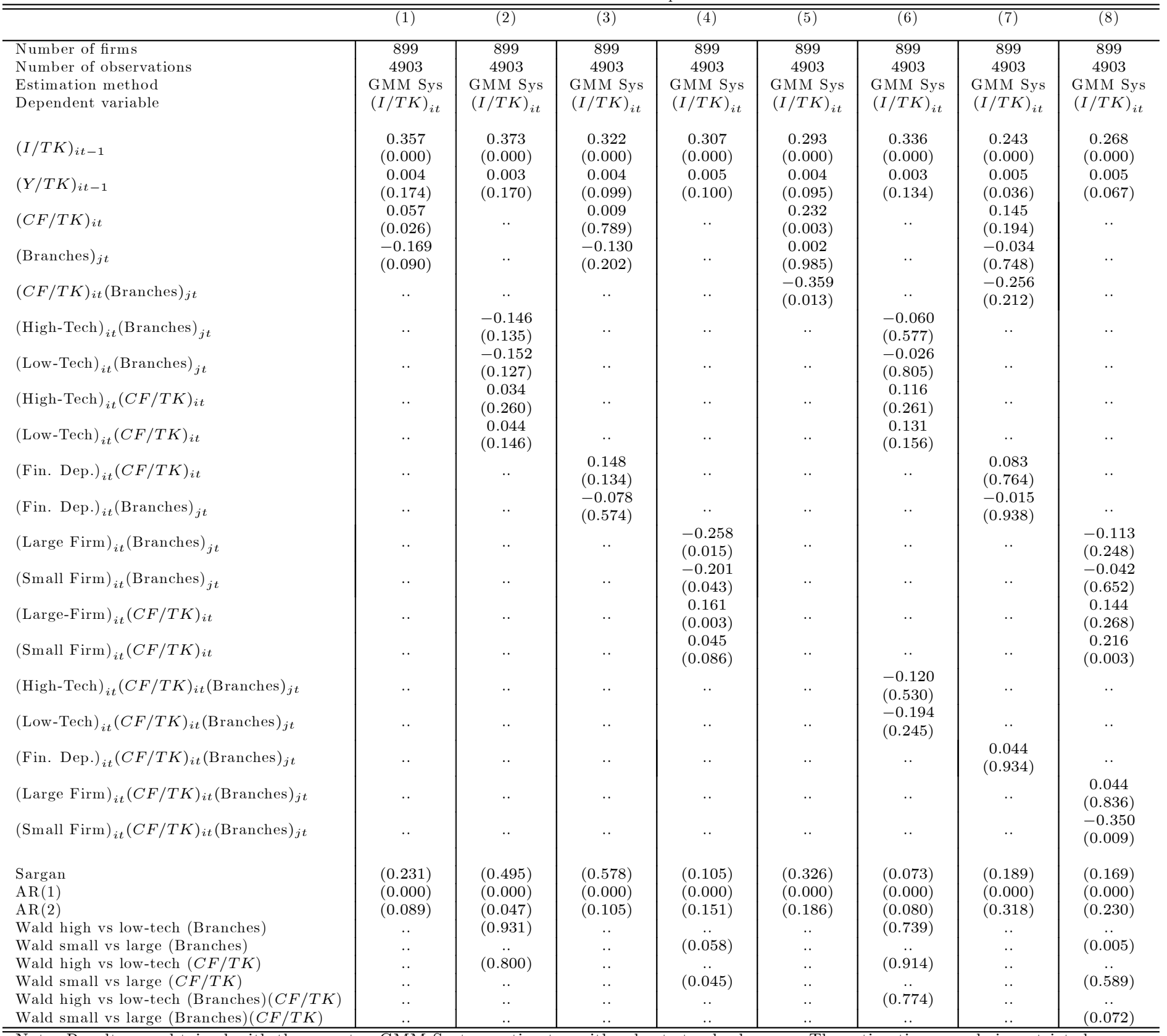

Note: Results are obtained with the one step GMM System estimator with robust standard errors. The estimation sample is restricted to firms with at least 6 contiguous observations. The instrument set includes the regressors dated t-2 and t-3. All equations include year, industry and regional dummies as regressors and instruments. P-values is round brackets. Sargan is a Sargan test of the validity of the overidentifying orthogonality conditions. AR(1) and $\mathrm{AR}(2)$ test the presence of first $(\mathrm{AR}(1))$ or second order serial correlation (AR(2)) in the transformed error. 
Table 15: Conditional Logit Models for R\&D Investments

\begin{tabular}{|c|c|c|c|c|}
\hline & $(1)$ & $(2)$ & $(3)$ & $(4)$ \\
\hline $\begin{array}{l}\text { Number of firms } \\
\text { Number of observations }\end{array}$ & $\begin{array}{c}538 \\
2910\end{array}$ & $\begin{array}{c}538 \\
2910\end{array}$ & $\begin{array}{c}538 \\
2910\end{array}$ & $\begin{array}{c}538 \\
2910\end{array}$ \\
\hline Estimation method & $\begin{array}{l}\text { Cond. } \\
\text { Logit }\end{array}$ & $\begin{array}{l}\text { Cond. } \\
\text { Logit }\end{array}$ & $\begin{array}{l}\text { Cond. } \\
\text { Logit }\end{array}$ & $\begin{array}{l}\text { Cond. } \\
\text { Logit }\end{array}$ \\
\hline Dependent variable & R\&D Exp. & R\&D Exp. & R\&D Exp. & R\&D Exp. \\
\hline$(\text { Firm Size })_{i t}$ & $\begin{array}{l}-0.000 \\
(0.558)\end{array}$ & $\begin{array}{l}-0.000 \\
(0.564)\end{array}$ & $\begin{array}{l}-0.000 \\
(0.537)\end{array}$ & $\begin{array}{l}-0.000 \\
(0.317)\end{array}$ \\
\hline$(C F / T K)_{i t}$ & $\begin{array}{c}0.381 \\
(0.006)\end{array}$ & .. & $\begin{array}{c}0.379 \\
(0.112)\end{array}$ & .. \\
\hline$(\text { Branches })_{j t}$ & $\begin{array}{c}3.295 \\
(0.048)\end{array}$ & .. & $\begin{array}{c}1.962 \\
(0.290)\end{array}$ & .. \\
\hline$(\text { High-Tech })_{i t}(C F / T K)_{i t}$ & . & $\begin{array}{c}0.765 \\
(0.001)\end{array}$ & .. & .. \\
\hline$(\text { Low-Tech })_{i t}(C F / T K)_{i t}$ & .. & $\begin{array}{c}0.124 \\
(0.494)\end{array}$ & $\cdot$. &.. \\
\hline$(\text { High-Tech })_{i t}(\text { Branches })_{j t}$ & .. & $\begin{array}{c}4.185 \\
(0.049)\end{array}$ & $\cdot$. & .. \\
\hline$(\text { Low-Tech })_{i t}(\text { Branches })_{j t}$ & .. & $\begin{array}{c}3.094 \\
(0.071)\end{array}$ & .. & .. \\
\hline$(\text { Fin. dep. })_{i t}(C F / T K)_{i t}$ & .. & .. & $\begin{array}{c}0.005 \\
(0.992)\end{array}$ & .. \\
\hline$(\text { Fin. dep. })_{i t}(\text { Branches })_{j t}$ & .. &.. & $\begin{array}{c}5.182 \\
(0.103)\end{array}$ & . \\
\hline$(\text { Small })_{i t}(C F / T K)_{i t}$ & .. & .. & $\cdot$. & $\begin{array}{c}0.381 \\
(0.009)\end{array}$ \\
\hline$(\text { Large })_{i t}(C F / T K)_{i t}$ & .. & .. &.. & $\begin{array}{c}0.884 \\
(0.082)\end{array}$ \\
\hline$(\text { Small })_{i t}(\text { Branches })_{j t}$ & .. & .. & .. & $\begin{array}{c}5.130 \\
(0.003)\end{array}$ \\
\hline$(\text { Large })_{i t}(\text { Branches })_{j t}$ & .. & .. & .. & $\begin{array}{l}-3.046 \\
(0.139)\end{array}$ \\
\hline Endogeneity test for Branches & $(0.35)$ & $(0.62)$ & $(0.65)$ & $(0.05)$ \\
\hline Wald high vs low-tech $(C F / T K)$ & .. & $(0.030)$ & .. &.. \\
\hline Wald high vs low-tech (Branches) & .. & $(0.524)$ & .. & .. \\
\hline Wald small vs large $(C F / T K)$ & .. &.. & .. & $(0.340)$ \\
\hline Wald small vs large (Branches) &.. &.. &.. & $(0.000)$ \\
\hline
\end{tabular}

Note: All regressions include two wave dummies. P-values in round barckets. Endogeneity test reports the p-value of the Rivers-Vuong test on the endogeneity of branches. 


\section{Data Appendix}

\subsection{Sample Selection}

The firm level data used in this work are obtained by merging the three most recent waves $(1995,1998$, 2001) of a comprehensive survey on Italian manufacturing firms carried out by Capitalia's Observatory on Small Firms every three years. Each wave reports standard balance sheet data for the previous three years (1992-94, 1995-97 and 1998-00 respectively) complemented by additional qualitative and quantitative information on several research issues including $R \& D$ and innovation. The three surveys include respectively 4431, 4497 and 4680 firms. As already mentioned in Section 2, all firms with more than 500 employees are included in each wave. Most of the firms with less than 500 employees are selected with a stratified sampling method in each wave. However, some of them (at the discretion of Capitalia) are kept in two consecutive waves. Therefore, even after conditioning on survival, the probability of finding a small firm in two separate waves is small.

We removed from the sample firms with missing or non-manufacturing activity codes, as well as firms with no indication of the location of headquarters. As we use provincial level instrument sets dated 1936 we removed firms located in four provinces (Isernia, Pordenone, Oristano and Caserta) created after 1936. Therefore our sample is composed by firms located in one of the remaining 91 provinces existing at the beginning of the 90's. Furthermore, we removed in each wave those with missing values or inconsistencies for the variables used in the econometric estimates or with extreme values for the variables. The first and last percentiles have been used as lower and upper thresholds for the trimming procedure. The following table describes our sample.

\begin{tabular}{ccccc}
\multicolumn{5}{c}{ Table A.1. Firms distribution by size and technology in each sample, $\%$} \\
\hline \hline & $1992-94$ & $1995-97$ & $1998-00$ & Total \\
Number of Firms before Cleaning & 4431 & 4497 & 4680 & 14592 \\
Number of Firms after Cleaning & 2055 & 2088 & 1882 & 6025 \\
of which Employees $\leq 250$ & 84.33 & 87.64 & 93.25 & 88.27 \\
Employees $>250$ & 15.67 & 12.36 & 6.75 & 11.73 \\
of which High-Tech & 35.47 & 31.42 & 29.91 & 32.33 \\
Low-Tech & 64.53 & 68.58 & 70.09 & 67.67 \\
\hline \hline
\end{tabular}

Note: A firm is defined as "High-Tech" if its main activity is one of the following:

Chemicals, Machinery, Computers, Electrical Machinery, TV-Radio,

Medical Apparels, Means of Transport. It is "Low-Tech" otherwise.

Some firms are sampled in more than one wave so that they appear more than once in our final sample. The following table describes the panel structure of the sample after the cleaning procedure.

Table A.2. Panel structure of the sample

\begin{tabular}{lccc}
\hline \hline & Total number of firms & High-Tech firms & Firms with employees $\leq 250$ \\
$1992-94$ only & 1476 & 486 & 1287 \\
$1995-97$ only & 1189 & 341 & 1090 \\
$1998-00$ only & 1236 & 353 & 1193 \\
$1992-94$ \& 1995-97 & 348 & 146 & 258 \\
$1992-94 \&$ 1998-00 & 95 & 41 & 80 \\
$1995-97 \&$ 1998-00 & 415 & 113 & 374 \\
$1992-94,1995-97 \&$ \& 1998-00 & 136 & 56 & 108 \\
\hline \hline
\end{tabular}




\subsection{Variables Definition}

Branches: Denotes the number of bank branches in a province divided by its populations, in thousands. Its contemporaneous value is computed as the average value over each of the periods covered by the Capitalia survey (1992-94, 1995-97, 1998-00). Its lagged value refers to 1991, 1994, and 1997 respectively.

Innovation dummies: the process (product) innovation dummy takes the value 1 if the firm has declared to have introduced at least one process (product) innovation in the period covered by the survey (1992-94, 1995-97, 1998-00), and zero otherwise.

Fixed Investment $(I)$ : yearly investment in plants and machinery as reported in the questionnaire deflated with the aggregate business investment price index.

R\&D Investment $(R \& D)$ : yearly $R \& D$ investment as reported in the questionnaire deflated with a weighted average of the consumer price index (0.8) and the aggregate business investment price index (0.2). Firms are provided with a definition of what has to be considered as R\&D investment consistent with the Frascati manual.

Fixed Capital $(K)$ : real fixed capital stock (at the end of the period), computed by a perpetual inventory method with a constant rate of depreciation $(\delta=0.05)$. The benchmark at the first year is the accounting value as reported in the balance sheet.

R\&D Capital $(G)$ : real R\&D capital stock (at the end of the period) computed by a perpetual inventory method with a constant rate of depreciation $(\delta=0.15)$. The benchmark for the first year is calculated assuming that the rate of growth in $R \& D$ investment at the firm level in the years before the first positive observation equals the average growth rate of industry level R\&D between 1980 and 1991. The initial stock at historical costs is revalued using the average inflation rate for the $R \& D$ deflator during the same period.

Total Capital $(T K)$ : computed as the sum of fixed capital $(K)$ and of R\&D capital $(G)$.

Cash Flow Intensity $(C F / T K)$ : ratio of cash flow over total capital stock at the beginning of the period.

Fixed Investment Intensity $(I / T K)$ : ratio of investment in fixed assets over total capital stock at the beginning of the period.

R\&D Investment Intensity $(R \& D / T K)$ : ratio of $\mathrm{R} \& \mathrm{D}$ investment over total capital stock at the beginning of the period.

Production Intensity $(Y / T K)$ : ratio of production over total capital stock at the beginning of the period.

Financial dependence: the Rajan-Zingales (1998) industry level variable has been used as a measure of financial dependence.

Size: it is measured by total capital stock.

Small and Large firms: the sets of small and large firms have been identified by using the 75 th percentile of the total capital stock distribution as threshold.

Age: it is computed as the central year of the survey (1993, 1996, 1999 respectively) minus the year of inception.

R\&D Consortium: the "R\&D Consortium" dummy takes the value 1 ( $1 \%$ of total observations) if the firm has declared to be part of a R\&D consortium in the period covered by the survey (1992-94, 1995-97, 1998-00), and zero otherwise (99\% of total observations).

Group: the "Group" dummy takes the value 1 (30\% of total observations) if the firm has declared to be part of a business group in the period covered by the survey (1992-94, 1995-97, 1998-00), and zero otherwise ( $70 \%$ of total observations).

Corporation: the "Corporation" dummy takes the value 1 (98\% of total observations) if the firm has declared to be a corporation in the period covered by the survey (1992-94, 1995-97, 1998-00), and zero otherwise ( $2 \%$ of total observations).

Industry Dummies: 21 industry dummies have been included in all equations reported in Tables from 5 to 9 and 12 (15+16 - food, beverages and tobacco; 17 - textiles; 18 - clothing; 19 - leather; 20 - wood; 21 - paper products; 22 - printing and publishing; 23 - oil refining; 24 - chemicals; 25 - rubber 
and plastics; 26 - non-metal minerals; 27 - metals; 28 - metal products; 29 - non-electric machinery; 30 - office equipment and computers; 31 - electric machinery; 32 - electronic material, measuring and communication tools, TV and radio; 33 - medical apparels and instruments; 34 - vehicles; 35 - other transportation; 36 - furniture). Each dummy takes the value 1 if the firm main activity is in that industry, and zero otherwise.

High-Tech and Low-Tech industries: The following industries have been considered as high tech ones: 24 - chemicals; 29 - non-electric machinery; 30 - office equipment and computers; 31 electric machinery; 32 - electronic material, measuring and communication tools, TV and radio; 33 - medical apparels and instruments; 34 - vehicles; 35 - other transportation. The High Tech dummy takes the value 1 for these industries and 0 otherwise.

Regional Dummies: 18 regional dummies have been included in equations reported in Tables from 5 to 9 and 12. To avoid collinearity with the time invariant instruments dated 1936 two regions with only one province (Molise and Valle d'Aosta) have been grouped with the nearest region (Piedmont and Abruzzi).

Provincial Dummies: 91 provincial dummies have been included in equations reported in Tables from 5 and 8. They correspond to the administrative structure of Italy in 1936.

Provincial Controls: 5 provincial level variables have been used in equations reported in Tables 5 and 6 . They are: i) the inefficiency of the legal system measured as the number it takes to complete a first degree trial (source: Guiso et al., 2004c); ii) a measure of social capital measured as voter turnout for all referenda before 1989 (source: Guiso et al., 2004c); iii) an index of infrastructures in 1990 (source: Confindustria); iv) the total number of plants in the province in 1991 (source: Istat); v) human capital measured as the level of education for people aged 19-44 in 1991 (source: Istat). 